\title{
Nederlandse bestuursrechtelijke appèlrechtspraak in transitie
}

\section{Enkele opmerkingen over de ontwikkelingen in de bestuurs- rechtspraak in hoogste instantie in Nederland}

Adrienne de Moor-van Vugt*

\section{Stand van zaken in de Nederlandse bestuursrechtspraak}

Bij de invoering van de Algemene wet bestuursrecht (Awb) in 1994 stond voor ogen dat het stelsel van bestuursrechtspraak in Nederland sterk vereenvoudigd zou worden. Van een situatie waarin tal van rechtsprekende colleges en instanties ieder hun eigen specifieke competentie en procesrechtelijke regels kenden, ${ }^{\mathrm{I}}$ zouden we overgaan naar een meer ideale situatie: één rechtsingang voor alle bestuursrechtelijke geschillen, geïntegreerd in de rechterlijke macht, één procesrecht, en hoger beroep bij één appèlinstantie met een algemene bevoegdheid. Dit zou garant staan voor snelle, effectieve rechtsbescherming en finale geschillenbeslechting. Zoals het gaat met veel idealen zijn we vol optimisme begonnen om te proberen de ideale situatie te verwezenlijken en kwamen we gaandeweg allerlei problemen en praktische bezwaren tegen, die ertoe hebben geleid dat we na zo'n tien jaar van gestage voortgang een pas op de plaats hebben moeten maken. In 2004 heeft de regering bericht de voor ogen staande uitvoering van de zogenoemde derde fase van de herziening van de rechterlijke organisatie ${ }^{2}$ geen doorgang te laten vinden, en het te willen houden bij de toen bestaande situatie. ${ }^{3}$ Dat was (en is nog steeds) integratie van de bestuursrechtspraak in eerste aanleg in de rechterlijke macht - zodat naast een sector civiel recht, een sector strafrecht en een (in de tweede fase van de herziening van de rechterlijke organisatie ingevoerde) sector kanton ook een sector bestuursrecht bij de rechtbanken zijn intrede heeft gedaan - en een geharmoniseerd bestuursprocesrecht in eerste aanleg, neergelegd in de Awb. Dit procesrecht is deels ook van toepassing op de procedures in hoger beroep. De 'oude' hoogste instanties, Afdeling bestuursrechtspraak Raad van State, Centrale Raad van Beroep, en College van

* Adrienne de Moor-van Vugt is raadsheer bij het College van Beroep voor het bedrijfsleven te 's-Gravenhage.

I. Zie hierover R.J.G.M. Widdershoven, Gespecialiseerde rechtsgangen in het administratieve recht W.E.J. Tjeenk Willink: Zwolle ig89.

2. Zie voor de voorgestelde scenario's de discussienota Keuzen voor de bestuursrechtspraak van I8 mei 200I, te vinden via http://www.justitie.nl/onderwerpen/wetgeving/awb/notas/.

3. Kamerstukken II 2003-2004, 25 425, nr. 7 Herziening rechterlijke organisatie. 
Beroep voor het bedrijfsleven - met ieder hun eigen absolute competenties in eerste aanleg en in hoger beroep - zijn gebleven. Een klein stapje voorwaarts is nog wel gezet bij het invoeren van belastingsrechtspraak in twee feitelijke instanties. Deze tak van rechtspraak is in eerste aanleg ondergebracht bij de rechtbanken, sectoren bestuursrecht, en in hoger beroep bij de hoven. De mogelijkheid van beroep in cassatie bij de Hoge Raad, die in andere bestuursrechtelijke zaken over het algemeen niet bestaat, ${ }^{4}$ is gebleven. ${ }^{5}$

De herziening van de rechterlijke organisatie staat nu al een paar jaar stil. Het uiteenlopen van de meningen over te zetten vervolgstappen komt voor een deel doordat de verschillende betrokken hoogste bestuursrechtelijke colleges fundamenteel anders denken over hun taken en werkwijzen, dit terwijl zij voor een belangrijk deel vergelijkbaar werk doen en daarbij dezelfde of equivalente rechtsregels toepassen. Hun taakopvatting zoals die tot uiting komt bij aspecten als de uitleg en toepassing van procesrechtelijke bepalingen, het object van het hoger beroep, de motivering van uitspraken, finale geschillenbeslechting en de taakverdeling tussen bestuur en rechter loopt vooralsnog zodanig uiteen dat tot op heden de verschillende scenario's voor het vormgeven van de derde fase ${ }^{6}$ hierop zijn gestrand. Dit alles wordt nog eens gecompliceerd door de omstandigheid dat deze colleges hun bestaansrecht deels ontlenen aan hun taak als rechter in enige en eerste aanleg. In dat kader speelt tevens de vraag in hoeverre deze instanties nog zelfstandig bestaansrecht zouden hebben als de eerste en enige aanleg zou overgaan naar de rechtbanken, hetgeen niet ondenkbaar is. Immers, ook in civiele zaken en in strafzaken bestaat een appèlgrens en kan van sommige vonnissen niet in hoger beroep worden gekomen. Voor de Raad van State komt daar dan nog bij dat dit Hoogste College van Staat kan bogen op een eeuwenoude traditie, waarin advisering en beslechting van geschillen tussen overheid en burger werden gecombineerd. De rechtspraak van het Europese Hof voor de Rechten van de Mens over de scheiding van functies bij de Raden van State heeft tot consequentie dat vraagtekens worden gezet bij de vanzelfsprekendheid waarmee in het debat over de derde fase wordt uitgegaan van het (ongewijzigd) voortzetten van de rechtsprekende functie van de Raad van State.

Uit het voorgaande blijkt dat de Nederlandse bestuursrechtspraak in hoogste instantie zich in een fase van transitie bevindt. De oude situatie van verschillende hoogste instanties is de afgelopen jaren langzaam afgebouwd naar een situatie waarin nog vijf hoogste bestuursrechters aan het werk zijn: de Afdeling bestuursrechtspraak van de Raad van State, de Centrale Raad van Beroep, het College van Beroep voor het bedrijfsleven, de Hoge Raad in belastingzaken en het Hof Leeuwarden (voor de bestuurlijke boetes bij verkeersovertredingen). De werkzaamheden van het Hof Leeuwarden zijn dermate specifiek, dat ze in het kader van dit preadvies

4. Hierop bestaan echter uitzonderingen. Wanneer het College van Beroep voor het bedrijfsleven of de Centrale Raad van Beroep in hun uitspraken begrippen uit de belasting- en premiewetgeving uitleggen of toepassen, bestaat de mogelijkheid tegen hun uitspraken beroep in cassatie bij de Hoge Raad in te stellen.

5. Zie voor een overzicht van de inrichting van de bestuursrechtspraak heden ten dage J.E.M. Polak, Bestuursrechtspraak, in: E.R. Muller/C.P.M. Cleiren, Rechterlijke macht, Studie over rechtspraak en rechtshandhaving in Nederland, Kluwer: Deventer 2006, p. 335-360 (p. 344-346).

6. Zoals uiteengezet in de nota Keuzen voor de bestuursrechtspraak. 
buiten beschouwing worden gelaten. De overblijvende instanties hebben - op wellicht de Hoge Raad na - in het kader van de harmonisatie van het bestuursprocesrecht, zoals dat in gang is gezet door de Awb, hun taken en hun werkwijzen opnieuw gedefinieerd. Op hun taakopvattingen en werkwijzen is wel kritiek gekomen uit de rechtsgeleerde literatuur en uit de maatschappij, en soms heeft in reactie daarop een bijstelling plaatsgevonden. ${ }^{7}$

De ontwikkelingen op dit punt zijn echter nog niet tot stilstand gekomen en de vraag is gerechtvaardigd langs welke lijnen deze ontwikkelingen zouden kunnen verlopen, om tot een zodanige inrichting van de hoogste bestuursrechtspraak te komen dat deze aansluit bij de maatschappelijke, nationaal-juridische en internationaal-juridische context. Binnen het bestek van dit preadvies is een diepgaande behandeling van deze vraag niet mogelijk. Ik zal dan ook volstaan met het aanstippen van enkele actuele vraagstukken, die mijns inziens een goede illustratie vormen van problematiek die in de transitiefase aan de orde is. Daarbij zal ik enkele vingerwijzingen geven voor de richting waarin kan worden gedacht om de oplossing van deze vraagstukken dichterbij te helpen. Daarbij moet worden bedacht dat de meningen die ik in dit stuk als de mijne heb verwoord uitsluitend mijn persoonlijke opvattingen betreffen.

\section{De onzekere toekomst van de hoogste bestuursrechtelijke colleges}

\section{I Scenario's}

In de discussienota Keuzen voor de bestuursrechtspraak zijn verschillende scenario's geschetst over de wijze waarop de organisatie van de rechtspleging in het bestuursrecht verder vorm zou kunnen krijgen na de integratie van de bestuursrechtspraak in eerste aanleg in de rechterlijke macht. Het eerste scenario voor de zogenoemde derde fase houdt in dat de bestuursrechtspraak in hoger beroep naar de gewone rechterlijke macht gaat en de integratie in de gewone rechtspraak in eerste aanleg volgt (volledige integratie). ${ }^{8}$ Het zou ook kunnen betekenen dat cassatie wordt opengesteld in bestuursrechtelijke zaken. Dit model van volledige integratie wordt over het algemeen het meest vereenzelvigd met de term 'derde fase', hoewel strikt genomen de andere scenario's ook de derde fase kunnen vormen van de reorganisatie van de rechterlijke macht.

Als tweede schetst de discussienota het scenario dat de bestuursrechtspraak in hoogste instantie wordt geconcentreerd in één of hooguit twee colleges buiten de rechterlijke macht. Zo zouden de Afdeling bestuursrechtspraak, de Centrale Raad van Beroep en het College van Beroep voor het bedrijfsleven samengaan, of zou het College van Beroep voor het bedrijfsleven worden samengevoegd met de Afdeling bestuursrechtspraak en zou de Centrale Raad blijven (gedeeltelijke concentratie). ${ }^{9}$

7. Zo heeft de Afdeling bestuursrechtspraak haar praktijk van een vrij summiere motivering van uitspraken aangepast.

8. P. $38-42$.

9. P. $42-45$. 
Het derde scenario houdt in dat de hoogste rechtspraak in de sociale zekerheid en het ambtenarenrecht (het financiële en sociale bestuursrecht) zou worden geïntegreerd in de gewone appèlrechtspraak, terwijl voor het ordenend bestuursrecht hoger beroep open zou blijven staan op de Afdeling en het College, al dan niet samengevoegd (het scenario van de gedeeltelijke integratie). ${ }^{\text {IO }}$

Het ideaal van volledige integratie dat in den beginne werd geformuleerd door de Staatscommissie herziening rechterlijke organisatie ${ }^{\mathrm{II}}$ werd door de Hoge Raad onderschreven: hoger beroep van bestuursrechtelijke zaken op de gerechtshoven en cassatie bij de Hoge Raad. ${ }^{12}$ De Raad van State stelde in hetzelfde jaar echter dat de invoering van cassatieberoep geen bruikbaar alternatief zou zijn voor het bereiken van rechtseenheid. ${ }^{\mathrm{I}}$ Enerzijds zou daardoor - meende de Raad van State - het probleem alleen worden verplaatst, omdat daardoor een extra kamer bij de Hoge Raad zou moeten worden ingericht, hetgeen toch weer afstemmingsproblemen met de andere kamers zou geven. Anderzijds zou cassatieberoep als zodanig ongeschikt zijn voor het ordenende bestuursrecht, waar het veelal gaat om de beoordeling van gevoerd beleid en de toepassing van beleid op concrete gevallen. Een dergelijke beoordeling zal lang niet altijd kunnen worden herleid tot het al dan niet geschonden zijn van beleidsregels, door de Hoge Raad aangemerkt als recht in de zin van artikel 99 RO, waaraan de Hoge Raad mag toetsen.

Hiermee lag er een fundamenteel verschil van mening tussen twee Hoge Colleges van Staat, welk verschil tot op heden onoverbrugbaar is gebleken. De Centrale Raad van Beroep en het College van Beroep voor het bedrijfsleven zijn vanzelfsprekend geen voorstander van de eigen opheffing. De regering heeft daarom zoals hiervoor al werd vermeld, de derde fase afgeblazen, zodat het palet van vier hoogste bestuursrechters voorlopig blijft bestaan. ${ }^{\mathrm{I}} 4$

\subsection{Probleempunten bij volledige integratie}

Als redenen heeft de regering aangedragen dat de eigen aard van de bestuursrechtspraak zich verzet tegen verdergaande integratie in de gewone rechterlijke macht en dat de kwaliteit van de bestuursrechtspraak wordt gediend met behoud van rechtspraak in hoogste aanleg door op de onderscheiden deelterreinen van het bestuursrecht gespecialiseerde colleges. ${ }^{15}$

Daarbij ziet de regering ook een probleem daarin dat bij integratie in de rechterlijke macht drie instanties zouden openstaan, hetgeen de regering voor grote delen van het bestuursrecht maatschappelijk ongewenst acht, omdat zo'n lange rechts-

\footnotetext{
Io. P. $45-47$.

II. Eindrapport Naar een nieuwe structuur van de rechterlijke organisatie, Kamerstukken II I988I989, 2I 206, nr. 2. Dit rapport is overigens nooit met de Kamer besproken. Zie over deze historie Polak, a.w. p. 337-343.

I2. Jaarverslag Hoge Raad 2001/2002, p. 9, te vinden op de site van de Hoge Raad (zie www.rechtspraak.nl).

I3. Jaarverslag Raad van State 200I, p. 29 e.v.

I4. Ik laat nu even het Hof Leeuwarden als hoogste rechter in Mulder-zaken (kleine verkeersovertredingen die bestuursrechtelijk worden afgedaan) buiten beschouwing.

I5. Kamerstukken II, 2003-2004, 25 425, nr. 7, p. I.
} 
gang op gespannen voet zou komen te staan met de gewenste economische en maatschappelijke dynamiek. ${ }^{16}$ Sprekend over de vraag of daar waar nu nog rechtspraak in eerste en enige aanleg bestaat het invoeren van een tweede instantie opportuun is, neemt de regering het standpunt in dat een tweede instantie niet nodig is, omdat het bestuur in de bezwaarfase het besluit al een keer opnieuw heeft overwogen en daarover al een rechtsoordeel heeft gegeven. ${ }^{17}$

Nadat de regering stopzetting van de herziening van de rechterlijke organisatie had aangekondigd, rees her en der kritiek op dit besluit. Het gedachtegoed achter de derde fase was immers nog steeds springlevend. De kritiek is helder verwoord door De Haan en hij hield een pleidooi voor het doorzetten van de derde fase, leidend tot een volledige integratie van de rechterlijke macht. ${ }^{\mathrm{I}}{ }^{8} \mathrm{Zijn}$ voornaamste argumenten daarbij waren dat daardoor de rechtseenheid tussen de deelgebieden van het bestuursrecht en tussen het bestuursrecht en de andere hoofdgebieden van het Nederlandse recht op die manier zou worden bevorderd, en dat daarbij de grensgebieden - het bestuursstrafrecht en het overheidsprivaatrecht - verder tot ontwikkeling zouden kunnen komen. Zijn bijdrage ondervond steun, maar ook kritiek. ${ }^{19}$ Het woord systeemdrift is wel genoemd (door de toenmalige minister van Justitie ${ }^{20}$ ), omdat de liefde voor een ordelijk en logisch systeem het bij sommigen won van een realistische 'Waar heb dat nou voor nodig?'-benadering. Daarmee doel ik op de vraag naar nut en noodzaak van een dergelijke operatie. Zo werd door sommigen het argument van de regering ondersteund dat een volledige integratie tot gevolg zou hebben dat de rechtsweg door de bestuursrechtelijke rechtsbescherming een lange zou worden met een bezwaarschriftenprocedure en drie rechterlijke instanties daaropvolgend, leidend tot een maatschappelijk onaanvaardbaar lange duur van de procedures (indien tot het einde toe gevolgd). ${ }^{2 \mathrm{I}}$

Dat de eigen aard van het bestuursrecht zich tegen verdergaande integratie zou verzetten, - zoals de regering stelt - zie ik niet meteen. Datzelfde argument zou dan gelden voor de integratie in eerste aanleg, en die is wonderwel uitgepakt. De wijze waarop de bestuursrechtspraak in Nederland zich historisch heeft ontwikkeld vormt echter wel een probleem dat zich niet zomaar laat oplossen. Immers, de bakermat van de bestuursrechtspraak is de Raad van State. Daar is het allemaal begonnen met aanvankelijk advisering over bestuursrechtelijke geschillen, en later zelfstandige rechtspraak. Wanneer de Hoge Raad als hoogste bestuursrechter zou gaan optreden, zou de rol van de Raad van State als bestuursrechter uitgespeeld zijn. Dit wordt in verschillende kringen ongewenst gevonden, onder meer omdat dan de als vruchtbaar geziene combinatie met de wetgevingsadvisering wordt tenietgedaan. Anderen, waaronder leden van de Tweede Kamer, menen dat de rechtspraak van het EHRM over functiescheiding tot consequentie heeft dat de combinatie losgelaten zal

I6. P. 5 .

I7. P. 8 .

I8. P. de Haan, Compromisvoorstel integratie rechterlijke macht, NTB 2005, 28 (en voor degenen die net als ik een voorkeur hebben voor de ouderwetse notatie: p. 215-220)

I9. Zie NTB 2005, 35-38 (p. 278-285) voor de reacties van A. ten Veen, R.J.N. Schlössels, J.L. Verbeek, en Ch.J. Langereis.

20. Kamerstukken II 2004-2005, 29 279, nr. 27, verslag van een algemeen overleg, p. 6.

2I. Zie bij voorbeeld Polak, a.w., p. 343 . 
moeten worden. Het belangrijkste inhoudelijke probleem voor het doorzetten van de derde fase is dan ook gelegen in een kwestie die de regering niet duidelijk benoemt: de positie van de nu bestaande colleges van hoogste bestuursrechtspraak, en in het bijzonder die van de Hoge Raad en de Raad van State. Bij invoering van bestuursrechtspraak in drie instanties met cassatie bij de Hoge Raad zou tot gevolg hebben dat het ene Hoge College van Staat (de Raad van State) onder toezicht zou komen van het andere (de Hoge Raad), als zou worden vastgehouden aan de rechtsprekende taak van de Raad van State.

Het specialisatie-argument scoort mijns inziens wel. Dat geldt zowel het instituut als degenen (rechters en ondersteuners) die het instituut bezetten. Immers, bij een gespecialiseerd college is een schat aan ervaring op het gebied van aanpak en organisatie van de behandeling van specifieke geschillen; er is een diepgaande kennis op het gebied van het materiële recht, en de mensen die het werk doen zijn doordat zij zich zetten aan geschillen van vergelijkbare materie in staat snel door te dringen tot de kern van het probleem. Dat de rechtsprekenden niet behoeven te rouleren naar andere rechtsgebieden is daarbij een pre. Het huidige roulatiebeleid binnen rechtbanken is erop gericht rechters maximaal drie tot vijf jaar op een bepaald rechtsgebied in te zetten. Om gespecialiseerd te raken op bepaalde terreinen van het bestuursrecht is dat veel te weinig, en rechters binnen de sectoren bestuursrecht klagen daar ook over. Dergelijke nadelen kunnen worden voorkomen als de appèlinstanties als gespecialiseerde eenheden gezien blijven worden. Of deze gespecialiseerde eenheden zoals ze nu bestaan, ook moeten blijven bestaan is een andere vraag. Dat de hoogste bestuursrechtelijke instanties gespecialiseerd moeten blijven, staat mijns inziens buiten kijf.

Dat het aantal instanties een probleem is vanwege economische en maatschappelijke belangen zie ik ook niet meteen. In civielrechtelijke zaken zijn vergelijkbare belangen betrokken en daar zijn drie instanties heel gewoon. Bij de invoering van een tweede feitelijke instantie in belastingzaken zag men het probleem kennelijk niet, want de invoering is gewoon doorgegaan. Wel is het mogelijk dat door de duur van de rechtsgang de redelijke termijn van artikel 6 EVRM in het gedrang komt. ${ }^{22}$ Die geldt echter ook in civiele en strafzaken en daarvoor vindt men van tijd tot tijd ook wel een oplossing. Het is jammer dat in dit kader niet een analyse is gemaakt van typen zaken waarvoor één instantie met voorafgaand een bezwaarprocedure voldoende is, typen zaken waarvoor zeker hoger beroep open moet staan en typen zaken die geschikt zijn voor cassatie. Waar in het civiele recht de kantonrechter zaken met een financieel belang onder een bepaalde grens in eerste en enige aanleg af kan doen, zijn er in het bestuursrecht ook zaken met een gering financieel en maatschappelijk belang, waarvoor één feitelijke instantie voldoende zou kunnen zijn (bagatelzaken). Deze instantie - die nu veelal bij de Afdeling bestuursrechtspraak en het College van Beroep voor het bedrijfsleven berust - zou dan mijns inziens bij de rechtbanken moeten worden opengesteld, al was het alleen maar omdat de partijen

22. Vgl. bijvoorbeeld ABRvS I4 maart 2007, AB 2007, 213, m.nt. A.M.L. Jansen, waarbij het totaal van bezwaarschriftenprocedure, beroep en hoger beroep net binnen de perken bleef. De redelijke termijn leek in gevaar, omdat de zaak bij de rechtbank om onopgehelderde redenen een jaar in de kast had gelegen. 
dan niet worden gedwongen helemaal naar Den Haag of Utrecht af te reizen. ${ }^{23}$ Hiermee wijk ik enigszins af van het standpunt van de VAR-commissie Rechtsbescherming, die zich uitspreekt voor een andere optie. Rechtspraak in enige aanleg hoort volgens de commissie meervoudig bij de hoogste rechter plaats te vinden, dit ter waarborging van de kwaliteit (het moet in één keer goed). ${ }^{24}$

Dan bestaat er een type zaken dat ingewikkeld is, maar waarvoor wel geldt dat de maatschappij er belang bij heeft dat zij snel worden beoordeeld door rechters met kennis van zaken. Voor dit type zaken zou men kunnen kiezen voor twee instanties, waarbij de mogelijkheid wordt opengesteld om een instantie over te slaan. Een bezwaarmaker kan nu reeds op grond van artikel 7:Ia Awb verzoeken om de bezwaarfase te mogen overslaan als deze naar verwachting slechts leidt tot een herhaling van zetten. Zo zou het ook mogelijk kunnen zijn om (al dan niet na bezwaar) de eerste aanleg over te slaan. Daarbij is het wel van belang dat het zaken betreft waarbij de feiten redelijk duidelijk zijn en het vooral gaat om beantwoording van de rechtsvraag. Als nog een uitgebreid feitenonderzoek moet geschieden, zal dat immers tijd kosten en spant men het paard achter de wagen. Omdat enig feitenonderzoek dan nog wel mogelijk moet zijn, ligt het niet voor de hand hiervoor het instituut van (sprong)cassatie te kiezen. Eventueel kan aan de mogelijkheid van het overslaan van de eerste aanleg de voorwaarde worden verbonden dat men gebruik maakt van professionele rechtsbijstand om zo te waarborgen dat niet ten onrechte van een instantie wordt afgezien enerzijds, en dat de hogere rechter een behoorlijk uitgekristalliseerde zaak voor zich krijgt anderzijds.

Al met al lijkt het belangrijkste probleem te liggen in de constitutioneelrechtelijke posities van de Hoge Raad en de Raad van State, een probleem dat niet zomaar kan worden opgelost.

\subsection{Derde fase niet helemaal van de baan}

De Tweede Kamer heeft intussen duidelijk gemaakt, dat zij zich niet neer zal leggen bij de keuze van de regering in 2004 om de derde fase (in de betekenis van herstructurering van de appèlinstanties) helemaal af te blazen. Deze kwam pregnant naar voren bij de behandeling van het wetsvoorstel over de herstructurering van de Raad van State. ${ }^{25}$ Hierin wordt voorgesteld naast de Afdeling bestuursrechtspraak een aparte Afdeling advisering in te stellen. Tot nu toe wordt de functie van (wetgevings)advisering uitgevoerd door de zogenoemde volle Raad, en bestaat geen aparte afdeling wetgevingsadvisering. Met de arresten Procola ${ }^{26}$ en Kleyn ${ }^{27}$ is een gevoel

23. De Centrale Raad van Beroep heeft ook dergelijke zaken, maar in zeer geringe mate. De toenmalige voorzitter van de Afdeling bestuursrechtspraak Hirsch Ballin sloot niet uit dat deze zaken op den duur uit het takenpakket van de Afdeling verdwijnen, Zie J.C.A. de Poorter en E.M.H. Hirsch Ballin, Enkele beschouwingen over de toekomst van de rechtspleging, met name in het bestuursrecht, in: E.R. Muller/C.P.M. Cleiren, Rechterlijke macht, Studie over rechtspraak en rechtshandhaving in Nederland, Kluwer: Deventer 2006, p. 647-665 (665).

24. Zie VAR-Commissie Rechtsbescherming, De toekomst van de rechtsbescherming tegen de overheid, Van toetsing naar geschillenbeslechting, Den Haag 2004, p. I45. Destijds maakte ik deel uit van deze commissie.

25. Kamerstukken II, 2006-2007, 30585.

26. EHRM 28 september $1995, \mathrm{AB}$ I995, 588, m.n.t ICvdV.

27. EHRM 6 mei 2003, AB 2003, 2II, m.nt. LV en BdW. 
van noodzaak ontstaan om de structuur van de Raad van State zodanig te wijzigen, dat staatsraden die betrokken zijn geweest bij de advisering over een concreet wetsvoorstel niet betrokken zullen zijn bij rechtspraak over 'dezelfde zaak' ${ }^{28}$ De regering wil nu een zodanige inrichting van de Raad van State bevorderen, dat deze 'EHRM-proof' is. De volle Raad blijft uiteraard in verband met andere grondwettelijke taken bestaan, maar de wetgevingsadvisering wordt ondergebracht bij een aparte afdeling. Daarbij zullen overigens staatsraden lid kunnen zijn van beide afdelingen, hetgeen niet helemaal logisch lijkt in het licht van de doelstellingen van de herstructurering. In de Tweede Kamer is daarom een amendement voorgesteld, inhoudende dat een staatsraad slechts in één van de twee afdelingen kan worden benoemd. ${ }^{29}$ Daarnaast worden ingevolge het wetsvoorstel staatsraden in buitengewone dienst benoemd in één van de afdelingen. De Tweede Kamer plaatst deze herstructurering mede in het teken van de derde fase, en sommige leden zien hier een mogelijkheid om het ertoe te leiden dat de derde fase alsnog nieuw leven wordt ingeblazen. ${ }^{30}$ Ex-voorzitter van de Afdeling bestuursrechtspraak en huidig minister van Justitie Hirsch Ballin heeft de kamer een open gesprek toegezegd over de derde fase. Daarbij benadrukte hij wel dat zich inmiddels een volledige en volwaardige rol van de Afdeling bestuursrechtspraak heeft uitgekristalliseerd als hoogste rechter in bestuursrechtelijke zaken. ${ }^{3 \mathrm{I}}$

De regering heeft intussen wel een aantal maatregelen aangekondigd om te voorzien in kwesties die in de nota Keuzen voor de bestuursrechtspraak werden aangesneden en die snel een oplossing behoeven. Daarvan zijn het instellen van een gemeenschappelijke rechtseenheidskamer en de instelling van een Afdeling advisering bij de Raad van State in dit kader het interessantst. Over de laatstgenoemde kwestie is hiervoor al een en ander opgemerkt. Over de rechtseenheid gaat de volgende paragraaf.

\section{Rechtseenheid en coördinatie van rechtspraak zonder derde fase}

Rechtseenheid is een belangrijke kwalitatieve eis die aan de rechtspraak wordt gesteld, mede ten dienste van de rechtszekerheid. De rechtseenheid op het gebied van het algemeen deel van het bestuursrecht is van groter belang geworden sinds de invoering van de Awb. Immers, waar verschillende hoogste bestuursrechters dezelfde algemene wetgeving gaan toepassen en uitleggen liggen divergenties op de loer. Hierdoor is behoefte ontstaan aan een vorm van bewaking van de rechtseenheid. De rechtseenheid waarop ik hier doel heeft vooral betrekking op het algemeen deel van het bestuursrecht en enige mate op de rechtseenheid tussen het bestuursrecht en het straf- en civiele recht. Er wordt ook wel gesproken over de rechtseenheid

28. Wat 'dezelfde zaak' is, is duidelijker geworden uit het arrest Sacilor-Lormines, EHRM 9 november 2006, nr. 654II/or.

29. Kamerstukken II 2006-2007, 30585, nr. 8, amendement De Wit.

30. Zie Kamerstukken II, 2006-2007, 30585 , nr. 5, verslag van een overleg met de vaste commissie voor Binnenlandse Zaken en Koninkrijksrelaties, p. 2-4.

3I. Handelingen II, 2006-2007, nr. 43, p. 2493-25I2 (2502 en 25II). 
binnen de bijzondere delen van het bestuursrecht, maar deze laat ik buiten beschouwing. ${ }^{32}$ Een belangrijk terrein waarop vooruitgang zou kunnen worden geboekt betreft rechtseenheid is gelegen in het bestuursprocesrecht. Na een bespreking van de stand van zaken op het gebied van de organisatie van de rechtseenheid op dit moment, zal ik in volgende paragrafen ingaan op een aantal onderwerpen, waarbij de coördinatie en de rechtseenheid op dit moment voorwerp van discussie zijn. Ik doel daarbij op de praktijk van prejudiciële verwijzingen en op vraagstukken rond de ambtshalve toepassing van het recht (onder meer van het gemeenschapsrecht).

In het kabinetsstandpunt over de tweede evaluatie van de $\mathrm{Awb}^{33}$ heeft de regering definitief gekozen voor het in stand laten van de huidige organisatie van het hoger beroep in de bestuursrechtspraak. Daarbij is aangegeven dat wel zou moeten worden voorzien in de rechtseenheid en daarvoor is een wetsvoorstel toegezegd. Dat wetsvoorstel is (bij mijn weten) nog niet ingediend, mede omdat de Kamer het niet eens is met de door de regering gemaakte keuze om de derde fase af te blazen. ${ }^{34}$ Met het tot stilstand komen van de herziening van de rechterlijke organisatie is ook de mogelijkheid om langs die weg te komen tot een rechtseenheidsvoorziening bij de Hoge Raad van tafel. ${ }^{35}$ De vraag rijst nu hoe de rechtseenheid van de rechtspraak van de verschillende appèlrechters kan worden verzekerd zonder derde fase? 36

Tot nu toe gaat dat met behulp van informele coördinatiemechanismen tussen de bestaande hoogste bestuursrechters en die hun vorm hebben gekregen in het CPO (Contactpuntenoverleg) en het EVO (extern voorzittersoverleg). ${ }^{37}$ Het CPO heeft plaats op het niveau van de ambtelijke ondersteuning van de betrokken rechterlijke colleges, waaronder ook de Hoge Raad inzake de belastingrechtspraak. Binnen het $\mathrm{CPO}$ worden onderwerpen voorbereid die vervolgens in het EVO worden besproken. Het zijn onderwerpen met betrekking tot het algemeen deel van het bestuursrecht en het bestuursprocesrecht, bijvoorbeeld het ambtshalve aanvullen van rechtsgronden, en met betrekking tot vraagstukken die aanpalen aan andere rechtsgebieden, zoals schadevergoeding. Het doel van het overleg is om uiteenlopende jurisprudentie op genoemde terreinen te voorkomen of te beëindigen, als voor dat uiteenlopen geen goede reden voorhanden is. Het mondt uit in afspraken 'waaraan de deelnemers aan het overleg zich gebonden achten in die zin, dat zij op zich nemen te bevorderen dat er binnen hun gerecht overeenkomstig de in het overleg overeengekomen algemene lijn wordt gehandeld. ${ }^{8}{ }^{8}$ Het gaat hier dus inderdaad om een vorm van coördinatie die op vrijwillige basis geschiedt. Zodra één der deelnemende partijen nut of noodzaak van een bepaalde lijn niet inziet, is deze daaraan ook niet gebonden. Dit betekent dat door de buitenwereld opgemerkte divergenties zullen blijven bestaan, daar

32. Zie over de verschillende percepties van rechtseenheid in het bestuursrecht J. van Erp c.s., Eenheid van rechtspraak, Een onderzoek naar de werking van coördinatiemechanismen in het bestuursrecht, B\&A Groep Beleidsonderzoek \& Advies, Den Haag $200 \mathrm{I}$.

33. Nota Rechtsstaat en Rechtsorde, Kamerstukken II 2003-2004, 29279, nr. I6.

34. Zie Kamerstukken II 2003-2004, 25425 nr. 7, p. 7.

35. Dat was wel het uitgangspunt bij de voltooiing van de eerste fase, zie Kamerstukken II I99I-I992, 22495, nr. 3, p. 55-62.

36. Zie voor verschillende opties het rapport van de VAR-commissie Rechtsbescherming, p. I45-I5I.

37. Zie hierover H. Bekker en J.H. van Kreveld, Coördinatie binnen de bestuursrechtspraak, in: R.M. Van Male (red), Centrale Raad van Beroep I903-2003, Sdu Uitgevers BV: Den Haag 2003, p. 29I-3I2.

38. Bekker/Van Kreveld, p. 301 . 
waar om welke reden dan ook een van de partijen zich niet committeert, met alle gevolgen voor de rechtszekerheid van dien.

Tijdens de behandeling van de discussienota Keuzen in de bestuursrechtspraak kwamen de uitkomsten van een onderzoek naar rechtseenheid in de bestuursrechtspraak ter beschikking. ${ }^{39}$ Deze resultaten heeft de regering gebruikt om de scenario's die in de discussienota zijn besproken nader te bezien. Daarbij heeft de regering erop gewezen dat de scenario's van volledige integratie en die van concentratie tot grote organisatorische en personele kwesties aanleiding zouden geven en de vraag opgeworpen of dit wel de moeite waard zou zijn als de rechtseenheid ook op een andere manier zouden kunnen worden gewaarborgd, namelijk door de instelling van een rechtseenheidskamer. Ook drie hoogste bestuursrechtelijke appèlrechters hebben destijds gepleit voor de instelling van een rechtseenheidskamer. ${ }^{40}$ Deze zou volgens de regering kunnen bestaan uit de voorzitter van de Afdeling bestuursrechtspraak, en de presidenten van het College van Beroep voor het bedrijfsleven en de Centrale Raad van Beroep. ${ }^{4 \mathrm{I}}$ Of de belastingkamer van de Hoge Raad zou moeten worden betrokken, is een vraag waarop toen geen eenduidig antwoord is gegeven. Mij lijkt dat dit met de huidige ontwikkelingen van belastingrechtspraak in eerste aanleg bij de rechtbanken, die daarbij de Awb toepassen, wel noodzakelijk is, mocht het zover komen.

In het geval bij een van de betrokken hoogste gerechten een rechtsvraag opkomt, die ook het rechtsgebied van de andere gerechten kan raken (meestal kwesties van algemeen bestuursrecht), en waarvan beantwoording noodzakelijk is voor het beoordelen van de concrete zaak, zou het betrokken gerecht de zaak moeten verwijzen naar de rechtseenheidskamer en deze een prejudiciële vraag moeten stellen. De rechtseenheidskamer geeft daarop een bindend antwoord.

Hirsch Ballin en De Poorter hebben erop gewezen dat een rechtseenheidskamer een toegevoegde waarde heeft ten opzichte van andere manieren om de rechtseenheid te bewaken. Het gaat dan daarom dat uitspraken van een rechtseenheidskamer op voor de buitenwereld duidelijk kenbare wijze inzicht kan bieden in het proces van rechtsontwikkeling..$^{2}$ Dit nu is mijns inziens niet uniek voor een rechtseenheidskamer, maar wel uniek is dat door de keuzes die juist deze kamer maakt duidelijk is dat we hier te maken hebben met een algemeen en breed te aanvaarden oordeel over bepaalde rechtsvragen. Deze legitimatie zal bewerkstelligen dat rechtsprekenden in eerste aanleg en in appèl de uitgezette lijn zullen gaan volgen in hun eigen uitspraken, hetgeen de rechtszekerheid ten goede zal komen. Ook zal dit ertoe leiden dat in bepaalde gevallen minder vaak hoger beroep zal worden ingesteld.

$\mathrm{Al}$ met al is onder de huidige omstandigheden het instellen van een rechtseenheidskamer te prefereren boven het handhaven van de huidige situatie, omdat intussen het gevaar blijft bestaan dat de verschillende hoogste bestuursrechters uiteen-

39. Dit was het hiervoor al aangehaalde onderzoek van J. van Erp c.s., Eenheid van rechtspraak, Een onderzoek naar de werking van coördinatiemechanismen in het bestuursrecht, B\&A Groep Beleidsonderzoek \& Advies, Den Haag 200I.

40. Zie Kamerstukken 200I-2002, 26352, nr. 6I, p. II en Jaarverslag Raad van State 200I, p. 26-27.

4I. Zie Kamerstukken 200I-2002, 26352, nr. 6I, p. II-I2.

42. J.C.A. de Poorter en E.M.H. Hirsch Ballin, a.w., p. 659. 
lopende uitspraken doen over vraagstukken van algemeen bestuurs(proces)recht. De hiervoor genoemde informele coördinatiemechanismen bieden weliswaar de mogelijkheid dit te voorkomen, maar de vraag naar de daadwerkelijke effecten ervan moet worden gesteld. Zeker is de jurisprudentie van de verschillende bestuursrechters elkaar dichter genaderd. De vraag is alleen of dit komt door bewuste coördinatie. Afgaand op gepubliceerde jurisprudentie en een eigen beperkte ervaring lijkt me dat de implementatie van de binnen het CPO en EVO gemaakte afspraken te wensen overlaat. Deze afspraken worden uiteraard onder de rechtsprekenden bekend gemaakt, maar of zij daardoor daadwerkelijk deel gaan uitmaken van het rechterlijk beleid is niet zeker. Daartoe is een gerichte implementatie noodzakelijk, welke niet altijd plaatsvindt. Mogelijk speelt daarbij een rol, dat genoemde afspraken enerzijds op een niet rechtsprekend niveau en anderzijds op leidinggevend niveau worden gemaakt. Dit staat mogelijk een vereenzelviging met de tot stand gebrachte afspraken en een verinnerlijking daarvan door de rechtsprekenden op de werkvloer in de weg. Daarnaast is het zo, dat een afspraak tot coördinatie regelmatig bestaat in de afspraak 'to agree to disagree', hetgeen de gedachte versterkt dat ieder op zijn eigen wijze kan blijven voortgaan. Wel is het zo dat de rechtsprekenden van de verschillende rechtscolleges zich goed op de hoogte stellen van bestaande jurisprudentie bij de andere colleges en zij trekken zich eventuele kritiek die wordt geuit in de rechtsgeleerde literatuur terzake van divergenties aan. Dit is een vorm van zelfdisciplinering die los staat van doelgerichte coördinatie en implementatie van de resultaten daarvan. Zolang geen andere vorm van rechtseenheidvoorziening bestaat, zal aan versterking van de informele vormen van coördinatie moeten worden gewerkt.

\section{$4 \quad$ Praktijk van prejudiciële verwijzingen}

Zoals hiervoor is uiteengezet, kent het Nederlandse stelsel van bestuursrechtspraak niet de mogelijkheid om aan eigen hoogste bestuursrechters, welke dan ook, prejudiciële vragen te stellen, al bestaan plannen om een stelsel van verwijzing naar een rechtseenheidskamer in te voeren. Van de bevoegdheid prejudicieel te verwijzen naar het Hof van Justitie in Luxemburg maken voornamelijk de hoogste bestuursrechters gebruik. Voor de procedurele inbedding van de beslissing tot verwijzing, noch van de voorbereiding van de te stellen vraag bestaan nationaalrechtelijke regels. Hetgeen aan praktijk is opgebouwd bij de verschillende rechtscolleges is voornamelijk gebaseerd op nationaal procesrecht en de procesregels en nuttige wenken van het Hof. ${ }^{43}$ Hiermee is tevens gezegd dat geen eenvormigheid bestaat met betrekking tot de procedurele inbedding. Dit heeft geleid tot kritiek onder meer op de verschillen in inrichting van de procedures, de onduidelijkheid voor partijen over hun procespositie, een te gevarieerd (of achterwege laten van dit) gebruik van rechterlijk bevoegdheden als het horen van partijen over de formulering van de verwijzing, het niet geven

43. Wenken voor de indiening van prejudiciële verzoeken voor de nationale rechters, Pb. $2005 \mathrm{C} \mathrm{I} 43 / \mathrm{I}$. 
van een voorlopige voorziening bij de verwijzing (schorsing van het bestreden besluit), en de grote variatie in dicta in verwijzingsuitspraken. ${ }^{44}$

Als belangrijk probleem zie ik dat voor partijen niet duidelijk is wat de gang van zaken is in geval van de voorbereiding van een prejudiciële verwijzing. ${ }^{45}$ De rechter is niet verplicht partijen voorafgaand aan de verwijzing te horen, al is dat wel een van de nuttige wenken van het Hof. Aangezien de nationale rechter ambtshalve een vraag kan stellen, kan het gebeuren dat partijen niet bij de voorbereidingen zijn betrokken en zich overvallen voelen. In het algemeen zal de rechter dit met toepassing van beginselen van een goede procesorde weten te voorkomen. In de handleiding die ten behoeve van Nederlandse rechters is opgesteld door een expertgroep wordt hierop ook gewezen. ${ }^{46}$ De praktijk is echter zeer wisselend. In sommige gevallen worden partijen in het geheel niet gehoord. In andere gevallen worden zij wel gehoord, maar wisselt het onderwerp van het horen. Het kan gaan om een standpunt over de omstandigheid dat een prejudiciële verwijzing aan de orde is als zodanig, maar het kan ook gaan over de precieze formulering van de verwijzing. Het zou uit een oogpunt van rechtszekerheid en goede procesorde naar mijn mening beter zijn als een dergelijk vrij fundamenteel beginsel tot uitdrukking zou worden gebracht in geschreven regels van bestuursprocesrecht. Daarenboven lijkt me dat geraden met het oog op de rechtseenheid in de behandeling van dit soort verwijzingen.

Een ander probleem is dat de bevoegdheid tot het doen van een tussenuitspraak op basis van het nationale procesrecht niet bestaat. 47 In de praktijk wordt wel gebruik gemaakt van een dergelijke figuur, die wordt gegoten in de vorm van een schorsing van de behandeling of van een heropening van het onderzoek. Dit heeft echter tot gevolg dat bevoegdheden die samenhangen met de einduitspraak, zoals die tot het geven van een voorlopige voorziening, niet kunnen worden gebruikt. Dit betekent dat een partij die schorsing wenst van de uitvoering van het bestreden besluit gedurende de prejudiciële procedure apart een procedure tot voorlopige voorziening moet beginnen, als deze zich dat al realiseert..$^{8}$ Een dergelijk verzoek wordt in de regel behandeld door een andere rechter dan die op de hoofdzaak zit, zodat discrepanties kunnen ontstaan met betrekking tot de inschatting van de spoedeisendheid of de materiële gegrondheid van het verzoek.

Inhoudelijk gezien kan een probleem zijn dat verschillende hoogste bestuursrechters over vergelijkbare onderwerpen van algemeen (bestuurs)procesrecht vragen stellen aan het Hof. Dit is bijvoorbeeld gebeurd met vragen over de terugvordering van subsidies die werden gefinancierd door de Europese Structuurfondsen ESF en

44. Zie T. Barkhuysen, De inpassing van de prejudiciële procedure in het Nederlandse bestuursrecht, in: T. Barkhuysen e.a., Europees recht effectueren, Algemeen bestuursrecht als instrument voor de effectieve uitvoering van EG-recht, Kluwer: Alphen aan den Rijn 2007, p. 325-350 (340-343).

45. Zo ook Barkhuysen, p. 342.

46. Handleiding prejudiciële procedure, opgesteld onder verantwoordelijkheid van de Eurogroep, een expertgroep van Nederlandse rechters. De handleiding is informatief en beoogt slechts praktische suggesties te doen.

47. In de derde evaluatie van de Awb is dit genoemd als een knelpunt dat al enkele jaren voortbestaat. Zie R.J.G.M. Widdershoven e.a., De Europese agenda voor de Awb, Derde evaluatie van de Algemene wet bestuursrecht 2006, Boom Juridische uitgevers: Den Haag 2007, p. I49-I50.

48. Of het echt een groot praktijkprobleem is, is maar de vraag, aangezien bestuursorganen meestal de uitvoering van een besluit uit eigen beweging opschorten. 
EFRO. Zowel de Afdeling bestuursrechtspaak als het College van Beroep voor het bedrijfsleven hebben vragen gesteld over de plicht tot terugvordering zoals neergelegd in de toepasselijke EG-verordening in relatie tot de bepalingen in de Awb over intrekking van vastgestelde subsidies. ${ }^{49}$ Het kan ook voorkomen dat over de noodzaak van het stellen van een prejudiciële vraag op een bepaald onderwerp verschillend wordt gedacht. Barkhuysen wijst erop dat de Hoge Raad, noch de Afdeling bestuursrechtspraak een noodzaak hebben gezien vragen te stellen over de ambtshalve toepassing van EG-recht, hoewel hun opvattingen uiteenlopen. Het College van Beroep voor het bedrijfsleven deed dit onlangs wel..$^{\circ}$ Dit betekent onder meer dat de andere rechtscolleges min of meer gebonden zijn aan de weergave van het leerstuk van de ambtshalve toepassing en ambtshalve aanvulling door het College, aangezien het Hof van diens lezing van de stand van het Nederlandse recht uitgaat. De uitspraken van het Hof die gebaseerd zijn op die lezing werken vervolgens erga omnes en zijn bindend voor alle nationale instanties en rechters. Hierna zet ik uiteen dat de verschillende hoogste bestuursrechters in Nederland verschillend denken over het onderwerp van ambtshalve toepassing, onder meer in relatie tot de functie van het hoger beroep. De uitkomsten van een prejudiciële procedure kan dan ook sommige hoogste bestuursrechters voor problemen stellen als die niet aansluiten bij de eigen opvatting en praktijk met betrekking tot een leerstuk van algemeen bestuurs(proces)recht. Barkhuysen beveelt in dit kader een betere coördinatie aan. ${ }^{{ }^{\mathrm{I}}}$ Dit type vragen is echter - gelet op het karakter en de periodiciteit van het overleg niet geschikt om te bespreken in CPO en EVO. In deze overleggen kunnen immers geen concrete zaken besproken worden.

Wel kan informeel enige uitwisseling plaatsvinden door elkaar op de hoogte te stellen van het voornemen een vraag te stellen. Zo kan worden voorkomen dat vergelijkbare zaken die bij de verschillende colleges aanhangig zijn op verschillende manieren worden aangevat. Dit blijft een moeizame weg, omdat immers de verschillende hoogste bestuursrechters niet kunnen en mogen betrokken raken bij concrete geschillen die bij de ander sub judice zijn.

De voor de hand liggende oplossing om ook hier de rechtseenheidskamer zijn licht over te laten schijnen, lijkt mij ongeschikt, alleen al vanwege de dubbele prejudiciële weg die dan wordt gevolgd. Daarnaast staat de gemeenschapsrechtelijke plicht van iedere rechter die een noodzaak aanwezig acht voor het stellen van een vraag in de weg aan het invoeren van een zeef of toezichtsmechanisme. Het instituut van een gezamenlijke AG-functie - in de vorm zoals ik die in paragraaf 6 voorstel zou hier wel soulaas kunnen bieden. Hier kan worden gesignaleerd dat op meer

49. CBb I6 maart 2006, LJN AV7337, (Stichting ROM-projecten), beantwoord door het Hof op 2I juni 2007, C-I58/06, LJN: BBI587, AB, 2007, 239, m.nt. H. Griffioen; ABRvS 30 augustus 2006, nr. 200505580/I (sociale werkvoorziening), AB 2007, 24I, m.nt. M.J. Jacobs, LJN: AY7I76, nr. 20050295I/I (gem. Rotterdam), LJN: AY7173, en nr. 200502898/I (West-Brabant), LJN: AY7175, AB 2007, 240, JB 2006, 303, m.nt. AJB.

50. CBb I7 mei 2005, AWB 02/I66I, 02/I845 en 02/I90I, LJN: AT5816, AB 2005, 282, m.nt. JHvdV; door het Hof beantwoord op 7 juni 2007, C-222/05-C-225/05, LJN: BA909o, AB 2007, 228, m.nt. R.J.G.M. Widddershoven, en CBb 9 november 2006, AWB 05/686, LJN: AZ2235, AB 2007, 67, m.nt. Ortlep en Verhoeven.

5I. A.w., p. 34I. 
plekken een vergelijkbare vraag aan de orde is en kunnen suggesties worden gedaan voor beslissingen omtrent verwijzing en formulering van de vraag. Het staat dan de betrokken rechtscolleges volledig vrij om - volledig geïnformeerd over andere zaken - een beslissing te nemen.

Een probleem - enigszins losstaand van dat van coördinatie en rechtseenheid binnen het Nederlandse bestuursrecht - dat aan nationale kant niet kan worden opgelost is dat het Hof zorgvuldig geformuleerde vragen herformuleert of simpelweg geen antwoord geeft op als eerste gestelde vragen. In geval meer vragen worden gesteld mag worden aangenomen dat de eerste voor de beoordeling van de zaak het hoogste belang heeft en dat de daarop volgende hetzij gelijkwaardig hetzij subsidiair van aard zijn. Meermalen vat het Hof verschillende vragen samen onder één noemer of beantwoordt de meest subsidiaire vraag zonder de andere vragen te beantwoorden..$^{2}$ Dit laat de nationale rechter achter met een probleem. Hij heeft geen antwoord gekregen op de primaire vraag en kan de oordeelsvorming die afhing van het antwoord op die vraag niet afmaken. Dit betekent dat een nieuwe lijn van oordelen moet worden ontwikkeld, waarvoor ook weer nieuw feitenonderzoek nodig kan zijn of een uitgebreide behandeling. Dit alles leidt tot een nog langere afdoeningstermijn, die al veel te lang was als gevolg van de duur van de procedure te Luxemburg. In geval afstemming met andere bestuursrechtelijke appèlcolleges heeft plaatsgevonden klemt dit te meer, omdat de behandeling van zaken mogelijk in afwachting van de via een andere rechter ingezette prejudiciële procedure zijn opgeschort. Wanneer vervolgens geen antwoord komt op de voor die procedures van belang geachte vraag, moet worden overwogen of niet alsnog een verwijzing naar het Hof moet plaatsvinden met nare gevolgen voor de afdoeningstermijn.

Ook komt het wel voor dat feiten door het Hof anders worden vastgesteld of worden aangevuld. Dit laatste stelt de (bestuursrechtelijke) appèlrechter - anders dan de cassatierechter ${ }^{53}$ - niet voor onoverkomelijke problemen, aangezien hij ook in appèl volledig bevoegd is de feiten vast te stellen en dat ook na beantwoording door het Hof bij hervatting van de behandeling van de zaak nog kan doen. Partijen kunnen dan in de gelegenheid worden gesteld schriftelijk te reageren en eveneens kan een nieuwe mondelinge behandeling plaatsvinden. Dit is overigens in het algemeen regel na afloop van de prejudiciële procedure, tenzij de uitkomst van de zaak dermate duidelijk is dat partijen geen behoefte meer hebben aan een zitting. Desondanks ontstaat hier een langere afdoeningsperiode dan anders het geval zou zijn geweest.

\section{$5 \quad$ De functies van het hoger beroep en de omvang van het geding}

\section{I De functies van het hoger beroep}

Het hoger beroep heeft naar wordt aangenomen drie functies: herkansing voor partijen, controle van de eerste aanleg en het bevorderen van de rechtseenheid. Afhankelijk van de opvatting die een appèlrechter heeft over de functie van het hoger

52. Zie bijv. HvJEG 2I juni 2007, C-I58/06, LJN: BBI587, AB, 2007, 239, m.nt. H. Griffioen.

53. Zie HR 22 december 2006, AB 2007, II6, m.nt. R. Ortlep en M.J.M. Verhoeven. 
beroep zullen de grenzen van de omvang van het geding ruim of juist strikt worden getrokken. Wanneer de herkansingfunctie voorop staat, zullen partijen ruime gelegenheid krijgen nieuwe grieven tegen het bestreden besluit aan te voeren en nieuw bewijs te leveren, ook al zijn die in eerste aanleg niet naar voren gebracht. Het gaat dan niet zozeer om toetsing van de uitspraak in eerste aanleg, maar om een (her)beoordeling van het volledige geschil. Dit is anders wanneer de controlefunctie en rechtseenheidsfunctie voorop staan. In dat geval is de uitspraak in eerste aanleg het voorwerp van controle en wordt gekeken of de eerste rechter het goed heeft gedaan. Zaken die bij hem niet zijn aangevoerd en bewijsmiddelen die niet zijn overgelegd worden buiten beschouwing gelaten. Immers, als de eerste rechter deze niet kende, heeft hij zich er niet over uitgelaten en valt er voor de appèlrechter niets te controleren. 54

Het valt op dat tussen de verschillende rechtsgebieden in Nederland verschillen in opvatting bestaan over de functies van het hoger beroep. Voor zover ik kan overzien, staat in het strafrecht duidelijk de herkansingsfunctie voorop. In het civiele recht lijkt dit ook het geval, al heeft het burgerlijk procesrecht op dit punt ook de inslag van controle op de eerste rechter. ${ }^{55}$ Opmerkelijk is het dat binnen het bestuursrecht geen eensluidende opvatting bestaat over de functie van het hoger beroep, en daarmee ook niet over de afbakening van de grenzen van het geding. Veel van de discussies over de omvang van het geding zijn hierop terug te voeren. Laten we daarom bezien welke opvattingen er leven.

Bij de tweede evaluatie van de Awb is vastgesteld dat de Afdeling bestuursrechtspraak en de Centrale Raad van Beroep verschillen in opvatting over de functie van het hoger beroep. In het rapport van de Commissie Boukema is dit samengevat. ${ }^{6}$ Van deze samenvatting maak ik hierna gebruik en vul die aan met recente literatuur en jurisprudentie.

Bij de Centrale Raad van Beroep zijn zowel uitspraken te vinden waarin de uitspraak in eerste aanleg tot object wordt genomen, als uitspraken waarin, als het ware over het hoofd van de eerste rechter heen, rechtstreeks het bestreden besluit lijkt te worden getoetst. 57 De Centrale Raad van Beroep stelt de herkansingsfunctie voorop, en is dan ook tamelijk ruimhartig in het toelaten van nieuwe gronden en argumenten in hoger beroep. Zelfs gronden of argumenten die in eerste aanleg terecht wegens strijd met een goede procesorde buiten beschouwing zijn gelaten, omdat zij bijvoorbeeld eerst ter zitting zijn aangevoerd, worden in hoger beroep

54. Zie voor een nadere toelichting en uitwerking R.J.G.M. Widdershoven e.a., Hoger beroep, Algemeen bestuursrecht, Boom Juridische uitgevers: Den Haag $200 \mathrm{I}$.

55. Zie voor deze opvattingen R.H. Happé e.a., Hoger beroep in de steigers, Boom Juridische uitgevers, Den Haag 200 .

56. Toepassing en effecten van de Algemene wet bestuursrecht, I997-200I, Verslag van de Commissie Evaluatie Awb II (Commissie Boukema), p. 26. Ik heb de versie die op internet staat gebruikt: http:// www.justitie.nl/images/Tweede\%2oevaluatierapport\%20_Commissie\%2oBoukema_tcm34-2034.pdf.

57. Schreuder-Vlasblom komt na een onderzoek van vijf jaargangen gepubliceerde jurisprudentie tot de conclusie dat vooral het bestreden besluit centraal staat, zie M. Schreuder-Vlasblom, Naar een voltooid appèl; de bijdrage van het vreemdelingenappèl aan de verdere ontwikkeling van het bestuursrechtelijk hoger beroep, in: Grieven in het bestuursprocesrecht, Raad van State: Den Haag 2006, p. 82. 
veelal toegelaten, omdat de wederpartij dan inmiddels wel voldoende gelegenheid heeft gehad om zich daartegen te verdedigen.

Het object van het hoger beroep is voor de Afdeling bestuursrechtspraak de uitspraak van de eerste rechter. In vreemdelingenzaken volgt dit uit artikel 85 Vreemdelingenwet, in andere zaken is deze benadering gebaseerd op de eigen opvatting van de Afdeling over de functie van het hoger beroep. De Afdeling heeft in haar jurisprudentie tot uitdrukking gebracht dat het hoger beroep een controle van de eerste aanleg inhoudt en verder de rechtsontwikkeling dient. De jurisprudentie van de Afdeling met betrekking tot de afbakening van de omvang van het geding is dientengevolge restrictiever. De hoofdlijn is, dat nieuwe gronden of ingrijpende nieuwe argumenten in hoger beroep slechts worden geaccepteerd, indien voor het niet eerder inbrengen daarvan een bijzondere rechtvaardiging bestaat; voor nieuwe argumenten lijkt overigens iets sneller zo'n bijzondere rechtvaardiging te worden aangenomen dan voor geheel nieuwe gronden. Voor het overige moeten de gronden voortbouwen op hetgeen in eerste aanleg qua feiten is aangevoerd. Alleen dan wanneer in de feitelijke grondslag in eerste aanleg voldoende aanknopingspunten zijn, krijgt appellant een nieuwe kans om nieuwe (rechts) gronden aan te voeren..$^{8}$

Deze verschillen worden wel verklaard uit de aard van de geschillen die de appèlrechters te beoordelen hebben. De Centrale Raad heeft voornamelijk tweepartijengeschillen en deze concentreren zich op de sociale zekerheid en ambtenarenzaken. Belangen van derden of grote maatschappelijke belangen zijn niet aan de orde. Daarbij komt dat in dit type geschillen de Centrale Raad staat in een traditie van rechtsbescherming van de individuele, als zwakker beschouwde, burger tegen de overheid. Deze krijgt daarom de kans fouten te herstellen in hoger beroep, en kan daar nog nieuwe argumenten inbrengen tegen het in eerste aanleg reeds bestreden besluit. De langere procedure wordt daarbij op de koop toe genomen. De Afdeling heeft vaak driepartijengeschillen, waarbij de herkansing voor de een verlies aan rechtszekerheid voor de ander betekent. Bovendien gaat het om een type geschillen van ordenend bestuursrecht, zoals ruimtelijke ordening, waarbij het maatschappelijk belang hoog is en de behoefte aan snelle duidelijkheid groot. Dat heeft tot gevolg dat in dit type geschillen partijen moeten worden gedwongen in een zo vroeg mogelijk stadium hun kaarten op tafel te leggen, zodat snel maximale duidelijkheid wordt verkregen. Bovendien moet het totaal van beroep en hoger beroep niet teveel tijd in beslag nemen. Door uit te gaan van de controlefunctie en geen nieuwe argumenten of bewijs te accepteren beperkt de Afdeling het feitenonderzoek tot een minimum, hetgeen tijdsbesparend werkt.

Helemaal gaat deze verklaring niet op. In de tweepartijengeschillen in vreemdelingenzaken is dit - als gezegd - een wettelijk uitgangspunt en kan een appellant geen gronden bijbrengen of stukken overleggen met betrekking tot aspecten die in eerste aanleg niet naar voren zijn gebracht. Uit de jurisprudentie blijkt verder dat de Afdeling ook in andere tweepartijengeschillen uitgaat van de restrictieve benadering. 59

58. Zie ABRvS 3 april 2000, AB 2000, 222, m.nt. MSV, I2 juli 2006, LJN: AY3667, AB 2006, 338, m.nt. RW, 2I februari 2007, LJN: AZ8988, AB 2007, I55, m.nt. A.T. Marseille.

59. Zie ABRvS i2 juli 2006, LJN: $\mathrm{AY}_{3} 667, \mathrm{AB} 2006,338$, m.nt. RW. 
De rechtspraak van het College van Beroep voor het bedrijfsleven is niet betrokken in het onderzoek in het kader van de tweede evaluatie van de Awb, vermoedelijk omdat destijds nog weinig ervaring was opgedaan met het hoger beroep. ${ }^{60} \mathrm{Er}$ is overigens geen reden om aan te nemen dat voor het College niet vergelijkbare overwegingen als voor de Centrale Raad van Beroep gelden. ${ }^{61}$

De Commissie Boukema heeft in dit verband het volgende aanbevolen:

'Aanbevelingen:

I. Als object van het geding in hoger beroep behoort de uitspraak van de eerste rechter te gelden.

2. Dit brengt mee, dat in hoger beroep geen onderdelen van het besluit kunnen worden aangevochten, die in eerste aanleg niet in geschil waren. In zoverre kan de omvang van het geschil in hoger beroep niet groter zijn dan de omvang van het geschil in eerste aanleg.

3. Met betrekking tot onderdelen van het besluit die in eerste aanleg in geschil waren, kunnen partijen in hoger beroep nieuwe gronden of argumenten aanvoeren, tenzij de goede procesorde zich daartegen verzet. De inhoud van het begrip 'goede procesorde wordt daarbij mede bepaald door de aard van het geschil, in het bijzonder het al dan niet betrokken zijn van derden. Met het oog op de kenbaarheid voor (potentiële) procespartijen is van belang, dat de rechtspraak meer stelselmatig motiveert, welke kenmerken van een geschil nopen tot een restrictief of juist tot een ruim beleid bij het toelaten van nieuwe gronden of argumenten.

4. $(\ldots)^{62}$

Hoe de appèlrechters in belastingzaken hier tegenaan kijken weten we nog niet. De rechtspraak in twee feitelijke instanties (met daarna nog cassatie bij de Hoge Raad) is pas sinds I januari 2005 ingevoerd, zodat het aan de vroege kant is om hierover uitspraken te doen. Toch is in het kader van de evaluatie van de belastingrechtspraak

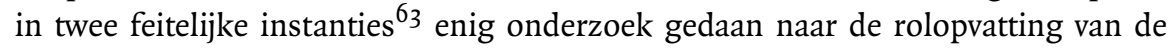
hoven in appèl. Daaruit blijkt dat alle hoven en de Hoge Raad de herkansingsfunctie in appèl voorop stellen. ${ }^{64}$ De mogelijkheid van herkansing geldt voor zowel de burger als de belastinginspecteur en heeft betrekking op nieuw bewijs, nieuwe gronden en zelfs niet eerder bestreden onderdelen van een besluit. Dit komt omdat de belastingaanslag als een en ondeelbaar wordt gezien, zodat - anders dan bij bij voorbeeld milieuvergunningen, waarbij onderdelen als luchtkwaliteit en waterkwaliteit

6o. In I997 werd voor het eerste hoger beroep opengesteld op het College van uitspraken van de rechtbank Rotterdam in mededingingszaken. Later zijn daar ook financiële toezichtszaken bijgekomen.

6I. CBb I april 2004, LJN: AO8207, AB 2004, 450, m.nt. P.A. Willemsen. Zie ook voor een overzicht van de opvattingen van de verschillende appèlcolleges P.A. Willemsen, De grenzen van de rechtsstrijd in het bestuursrechtelijk beroep en hoger beroep in rechtsvergelijkend perspectief, Kluwer: Deventer 2005, p. 269-274.

62. P. 28.

63. R.J.G.M. Widdershoven c.s., Evaluatie belastingrechtspraak in twee instanties, Eindrapport fase I, Raad voor de rechtspraak, Research Memoranda nr.3, jaargang 2, 2006, ook te vinden op www. rechtspraak.nl/gerechten/rvdr, rubriek wetenschappelijk onderzoek.

64. P. 32 . 
als afzonderlijke onderdelen worden gezien - geen aparte onderdelen kunnen worden afgesplitst. De goede procesorde is bepalend voor het antwoord op de vraag tot welke van fase van het hoger beroep nog met nova kan worden gekomen. ${ }^{65} \mathrm{De}$ opvattingen die de hoven in het onderzoek naar voren hebben gebracht komen sterk overeen met de opvatting van de Centrale Raad van Beroep ten aanzien van de functie van het hoger beroep. Ook de hoven hebben aangegeven dat het niet noodzakelijk is dat een appellant zijn grieven richt tegen de uitspraak van de rechtbank, al heeft dat wel de voorkeur. Het lijkt erop dat de hoven de aanslag als het object van geschil beschouwen en niet zozeer de uitspraak in eerste aanleg. ${ }^{66}$ Of en in hoeverre deze opvattingen ook werkelijk zullen worden doorgezet in de praktijk moet nog worden afgewacht. ${ }^{67}$

De opvatting over de functie van het hoger beroep kleurt als gezegd de wijze waarop het beroep vervolgens wordt behandeld, welke eisen worden gesteld aan het beroepschrift en de wijze waarop de omvang van het geding wordt afgebakend. Daarnaast heeft genoemde opvatting ook invloed op de mate waarin de appèlrechter zich bevoegd acht ambtshalve gronden bij het beroep te betrekken en de wijze waarop na een eventuele vernietiging van de aangevallen uitspraak de zaak wordt afgedaan. Deze onderwerpen worden hierna aangestipt.

\subsection{De inrichting van het beroepschrift}

Ingevolge artikel 6:5, eerste lid, Awb bevat het beroepschrift, ook in hoger beroep, de gronden van het beroep. Dit zijn de redenen waarom de appellant zich niet kan verenigen met de uitspraak in eerste aanleg. Deze kunnen betrekking hebben op de feitenvaststelling, op het inhoudelijk oordeel van de rechtbank of op de motivering daarvan. Het is niet nodig precies aan te geven tegen welke vaststelling of rechtsoverweging het beroep zich richt. De wettelijk bepaling sluit niet uit dat ook in brede termen gestelde, of zeer beperkt geformuleerde hoger beroepschriften ontvankelijk zijn, evenals beroepschriften waarin niet de uitspraak van de rechtbank, maar het in eerste aanleg bestreden besluit op de korrel wordt genomen. De gronden kunnen later ook worden aangevuld, al moet in het beroepschrift wel een begin van een aanduiding zijn waarom men in hoger beroep komt. De achtergrond hiervan is gelegen in ongelijkheidscompensatie: men kan in het bestuursrecht ook in hoger beroep zonder professionele rechtsbijstand procederen, zodat zo min mogelijk formele eisen worden gesteld aan het beroepschrift en het aan de rechter wordt overgelaten om de gronden verder aan te vullen (artikel 8:69 Awb, zie hierover nader hierna). Overigens kan men wel gebruik maken van rechtsbijstand door een advocaat of door een andere gemachtigde, zoals een accountant of een juridisch adviseur. In geval men gebruik maakt van professionele rechtsbijstand kan men ook in aanmerking komen voor vergoeding van de kosten van deze bijstand.

Op deze plaats moet nog worden gewezen op de bijzonderheid van het hoger beroep in vreemdelingenzaken, dat door de Afdeling bestuursrechtspraak wordt

65. Zie voor een overzicht p. 33-34 van genoemd rapport.

66. P. $35-36$.

67. Dit is onderwerp van Fase II van het evaluatie-onderzoek. 
behandeld. In afwijking van het algemene bestuursprocesrecht geldt voor dit hoger beroep op grond van artikel 85 Vreemdelingenwet een grievenstelsel. Een grief omschrijft het onderdeel van de uitspraak waarmee de indiener zich niet kan verenigen en de gronden waarop hij zich daarmee niet kan verenigen. Deze omschrijving moet concreet zijn en toegesneden op de aangevallen overwegingen. ${ }^{68}$ Als niet is voldaan aan de eis dat het beroepschrift een of meer grieven tegen de uitspraak in eerste aanleg bevat, wordt het hoger beroep niet ontvankelijk verklaard. ${ }^{69}$ Het aanvullen van de gronden van het hoger beroep is dan ook niet mogelijk. De Afdeling heeft de bevoegdheid zich te beperken tot een beoordeling van deze aangevoerde grieven en om grieven die niet tot vernietiging van de uitspraak in eerste aanleg nopen zonder nadere motivering af te doen (artikel 9I Vreemdelingenwet). ${ }^{70}$ In geval vragen spelen die in het belang van de rechtseenheid, de rechtszekerheid of de rechtsontwikkeling moeten worden beantwoord zal de Afdeling doorgaans wel gemotiveerd ingaan op grieven, ook al kan dat niet tot vernietiging van de uitspraak leiden. ${ }^{7 \mathrm{I}}$ Dit systeem is ingevoerd om een snelle afhandeling van de grote hoeveelheden hoger beroepen in vreemdelingenzaken te bevorderen.

In de literatuur wordt wel gepleit voor de invoering van een (milde vorm van) een grievenstelsel in het hoger beroep om op die manier niet alleen de proceseconomie te dienen, maar ook door een betere uitkristallisering van de aan de orde zijnde rechtsvragen de rechtseenheid te bevorderen alsmede de rechtsvorming door appèlrechters. ${ }^{72}$

\subsection{Het onderzoek in hoger beroep}

\subsubsection{Onderzoek van feiten}

De appèlrechters in het bestuursrecht hebben allen de bevoegdheid om de feiten (opnieuw) te onderzoeken en vast te stellen. Afhankelijk van de opvatting van de appèlrechter over het object en de functie van het hoger beroep zal hij de feitenvaststelling door de rechtbank al of niet tot uitgangspunt nemen. In geval de uitspraak van de rechtbank als object wordt gezien en het hoger beroep niet als een herkansing zal de appellant tegen de vaststelling van de feiten door de rechtbank gronden moeten aanvoeren. Anders worden deze door de appèlrechter als vaststaand

68. Kamerstukken II I998-I999, 26 732, p. 82.

69. Zie voor een overzicht van niet ontvankelijke beroepen H. G. Lubberdink, Het grievenstelsel in de rechtspraak van de Afdeling bestuursrechtspraak van de Raad van State in vreemdelingenzaken, in: Grieven in het bestuursprocesrecht, Raad van State: Den Haag 2006, p. 29-44.

70. Dit betekent overigens wel dat de Afdeling eveneens de bevoegdheid heeft om door appellant aangevoerde gronden - eenmaal de ontvankelijkheidsbarrière van artikel 85 genomen - in grieven te vertalen. Van die bevoegdheid maakt de Afdeling echter geen gebruik. Zie M. Schreuder-Vlasblom, Naar een voltooid appèl; de bijdrage van het vreemdelingenappèl aan de verdere ontwikkeling van het bestuursrechtelijk hoger beroep, in: Grieven in het bestuursprocesrecht, Raad van State: Den Haag 2006, p. 96.

71. Zie ABRvS 26 juni 200I, 200102683/r.

72. Zie bij voorbeeld J.E.M. Polak, Een grievenstelsel in het bestuursrecht, in: R.H. Happé e.a., Hoger beroep in de steigers, Boom Juridische uitgevers: Den Haag 200I, p. 63-70, en Schreuder-Vlasblom in haar bijdrage in Grieven in het bestuursprocesrecht, Raad van State: Den Haag 2006. 
beschouwd. Nieuwe feiten (waarover de rechtbank niet heeft kunnen oordelen) kunnen in beginsel niet worden aangevoerd, tenzij zij dienen ter nadere onderbouwing van een reeds in beroep in eerste aanleg ingenomen stelling. In geval het hoger beroep wordt beschouwd als een volledige herkansing zal de appèlrechter zelf feitenonderzoek doen en ook nieuw aangevoerde feiten onderzoeken en vaststellen.

De appèlrechter beschikt net als de rechter in eerste aanleg over een aantal onderzoeksbevoegdheden om de feiten te kunnen achterhalen. Daaronder bevindt zich de bevoegdheid tot het bij beide partijen en derden opvragen van stukken (waarvan uit het overgelegde dossier blijkt dat deze bestaan) en schriftelijke inlichtingen (artikel 8:45 Awb), het horen van partijen tijdens een inlichtingencomparitie (artikel 8:44 Awb), het horen van getuigen (artikel 8:46 Awb), het doen uitvoeren van een deskundigenonderzoek (artikel 8:47 Awb), het doen van onderzoek ter plaatse (artikelen 8:50 en 8:5I Awb), en het horen van getuigen en deskundigen ter zitting (artikelen 8:60 en 8:63 Awb). Uit onderzoek blijkt dat rechters in eerste aanleg de onderzoeksbevoegdheden van de Awb (op die tot het opvragen van stukken en schriftelijke inlichtingen na) nauwelijks benutten. ${ }^{73} \mathrm{Er}$ zijn geen gegevens over de praktijk in hoger beroep, al is mijn indruk dat het daar niet veel anders gaat.

\subsubsection{Ambtshalve aanvulling van rechtsgronden}

Voor de bestuursrechter bestaan twee mogelijkheden om ambtshalve - zonder dat partijen daarom hebben verzocht - toepassing te geven aan rechtsregels. De ene mogelijkheid bestaat in de toepassing van bepalingen die worden aangemerkt als van openbare orde (hierna aangeduid als ambtshalve toepassing). De andere mogelijkheid betreft de ambtshalve aanvulling van door partijen bijgebrachte gronden (artikel 8:69, tweede en derde lid Awb). Het gaat daarbij om het aanvullen van hetgeen door partijen is aangevoerd wat betreft de feiten of het recht met relevante toepasselijke wettelijke bepalingen of andere rechtsregels, zoals de algemene beginselen van behoorlijk bestuur of bepalingen van internationaal recht.

Op grond van artikel 8:69, eerste lid, Awb doet de bestuursrechter uitspraak op de grondslag van het beroepschrift, de overgelegde stukken, het verhandelde tijdens het vooronderzoek en het onderzoek ter zitting. Deze bepaling geldt ook in hoger beroep. Op die manier wordt de omvang van het geding afgebakend. Hetgeen buiten die afbakening valt, moet buiten beschouwing blijven. Dit betekent dat het in beginsel de partijen zijn die bepalen waarover het beroep gaat, en dat de rechter niet mag treden buiten de grenzen van het afgebakende geding, ook al ziet hij andere gebreken in het bestreden besluit of de bestreden uitspraak.

De appèlrechter is in beginsel gebonden aan de beperkingen die de appellant heeft aangebracht in de omvang van het geding, doordat hij bijvoorbeeld slechts tegen een onderdeel van de uitspraak opkomt (bijvoorbeeld over proceskosten of schadevergoeding) of tegen een oordeel over slechts een (afsplitsbaar) deel van het bestreden besluit (bijvoorbeeld over de hoogte van een bestuurlijke boete en niet over de

73. T. Barkhuysen c.s., Feitenvaststelling in beroep, Derde evaluatie van de Algemene wet bestuursrecht 2006, Boom Juridische uitgevers: Den Haag 2007, p. 199-232, ihb p. 228. 
gerechtvaardigdheid van de oplegging ervan). Op andere delen van de uitspraak of het bestreden besluit kan de appèlrechter in zo'n situatie in beginsel niet ingaan.

\subsubsection{Geen incidenteel appèl}

Terzijde: dit kan leiden tot problemen voor de verwerende partij. Die is mogelijk tevreden geweest met het oordeel van de rechtbank en heeft geen aanleiding gezien in hoger beroep te gaan, ook al heeft de rechtbank een aantal oordelen gegeven waarmee verweerder het niet eens was. Omdat het beroep om andere redenen gegrond is verklaard, is deze partij echter niet in hoger beroep gekomen.

In het voorontwerp Wet aanpassing bestuursprocesrecht is een voorbeeld, ontleend aan het rapport van de Commissie Boukema opgenomen: ${ }^{74}$

'Een gemeente krijgt subsidie van het rijk voor de aanleg van een nieuwe openbaar-vervoer-verbinding. Bij de definitieve vaststelling van de subsidie ontstaat een geschil. Volgens de gemeente acht de minister vijf kostenposten ten onrechte niet subsidiabel. Na beroep stelt de rechtbank ten aanzien van twee kostenposten de gemeente in het gelijk en ten aanzien van de andere drie de minister. De gemeente berust in deze uitspraak, maar de minister gaat in hoger beroep. De beroepsgronden van de minister hebben uiteraard slechts betrekking op de twee kostenposten ten aanzien waarvan hij in het ongelijk is gesteld. Dit betekent dat de andere drie kostenposten in hoger beroep niet meer ter discussie staan. Dit kan ongelukkig uitpakken. Wellicht heeft de gemeente, hoewel zij slechts gedeeltelijk in het gelijk is gesteld, in de uitspraak van de rechtbank berust om "van de zaak af te zijn". In dat geval betekent het hoger beroep van de minister dat de gemeente tegen haar zin betrokken blijft bij een procedure, waarin zij bovendien inmiddels niets meer kan winnen, maar nog wel verliezen. Omgekeerd kan de minister er ten opzichte van de uitspraak van de rechtbank wel op vooruit, maar niet meer op achteruit gaan.

Het enige wat de gemeente hiertegen kan doen is alsnog zelf ook hoger beroep instellen. Maar als de minister zijn hoger beroep pas tegen het einde van de termijn heeft ingesteld, kan dat in de praktijk heel moeilijk of zelfs onmogelijk worden.'

Voor deze situatie heeft de VAR-commissie Rechtsbescherming in navolging van de Commisisie Boukema voorgesteld om de mogelijkheid van incidenteel appèl in te voeren. Het bestuursprocesrecht kent deze mogelijkheid - anders dan het burgerlijk procesrecht - niet. ${ }^{75}$ De regering heeft dit voorstel opgenomen in het voorontwerp Wet aanpassing bestuursprocesrecht. ${ }^{76}$ In het belastingrecht bestaat deze mogelijkheid inmiddels (zie artikel $27 \mathrm{~m}$ Algemene wet inzake rijksbelastingen).

Dit probleem is acuter geworden, omdat de Centrale Raad van Beroep - in afwijking van eerdere jurisprudentie - inmiddels niet meer toelaat dat degene die niet in hoger beroep is gekomen, toch eigen gronden aanvoert in zijn reactie op het hoger-

74. Te vinden op http://www.justitie.nl/images/MvT\%2oWet\%2oAanpassing\%2obestuursprocesrecht_tcm34-2099.pdf.

75. VAR-commissie p. II7-II8; dit voorstel wordt breed gedragen. Zie het rapport van de Commissie verbetervoorstellen bestuursrecht, p. 20, het kabinetsstandpunt naar aanleiding van het rapport van de Commissie Boukema, Kamerstukken II, 2003-2004, 29279, nr. I6.

76. Voor commentaren op de voorstellen zie NTB 2006, afl. 8. 
beroepschrift. De oude jurisprudentie hield in dat verweerder in hoger beroep eigen bezwaren kon aanvoeren tegen de uitspraak in eerste aanleg als deze gronden voldoende nauw samenhingen met de door appellant aangevoerde gronden. Daarbij achtte de Centrale Raad een dergelijke nauwe samenhang aanwezig tussen bij voorbeeld de medische en de arbeidskundige kant van een geschil over arbeidsongeschiktheid. ${ }^{77}$ Recent heeft de Centrale Raad echter afscheid van deze jurisprudentie genomen, en geoordeeld dat niet een zodanige samenhang bestaat tussen de medische en arbeidskundige gronden dat de rechter als slechts medische gronden zijn aangevoerd ook ambtshalve arbeidskundige gronden bij de beoordeling moet betrekken. Dit betekent dat wanneer het uitkeringsorgaan in hoger beroep komt vanwege de beoordeling van de medische grondslag van een besluit door de eerste rechter, de aanvrager van de uitkering, verweerder in hoger beroep, geen mogelijkheid heeft om ook het arbeidskundige aspect nog aan de orde te stellen. ${ }^{78}$ De Afdeling bestuursrechtspraak was altijd al veel strenger hierin.

\subsubsection{Aanvullen binnen de grenzen van het geding}

Binnen de omvang van het geding mag de bestuursrechter ambtshalve de feiten aanvullen en tevens de rechtsgronden aanvullen. Omdat partijen nu eenmaal de omvang van het geding bepalen, mag dit aanvullen niet leiden tot verslechtering van de rechtspositie van de appellant (geen reformatio in peius). Over de bevoegdheid tot het ambtshalve aanvullen, in het bijzonder van de rechtsgronden, bestaat veel literatuur en veel rechtspraak. Ik zal dat niet herhalen maar verwijs in de noot naar enkele overzichtspublicaties. ${ }^{79}$

Uiteraard zit het belangrijkste probleem in het bepalen wat nu wel of niet binnen de omvang van het geding valt. Daarbij kan men een strenge lijn hanteren waarbij rechterlijk activisme uit den boze is en het aan partijen wordt overgelaten invulling te geven aan het geding en de grenzen ervan. Of men kan juist benadrukken dat het de taak van de rechter is zo goed mogelijk over het voetlicht te krijgen wat de kern van het geschil is, waarbij hij actief moet sturen om dit duidelijk te krijgen. Bij het actieve sturen kan horen dat hij tijdens de zitting gericht aan de orde stelt dat uit de stukken blijkt dat bepaalde door partijen niet betrokken wettelijke bepalingen of regels van ongeschreven recht geschonden zijn. ${ }^{80}$ Partijen kunnen vervolgens reageren en eventueel duidelijk maken dat het in het geheel niet hun bedoeling is de door de rechter genoemde rechtsregel te betrekken in het geding. ${ }^{8 \mathrm{I}}$

77. CRvB I8 december 1998 , JB I998, I8 m.nt. RJNS.

78. CRvB I7 april 2007, AB 2007, I67, m.nt. G.J. Vonk.

79. Zie uitgebreid over de problematiek van de afbakening van de omvang van het geding, ook in hoger beroep: P.A. Willemsen, De grenzen van de rechtsstrijd in het bestuursrechtelijk beroep en hoger beroep in rechtsvergelijkend perspectief, Kluwer: Deventer 2005; verder M. Schreuder-Vlasblom, Rechtsbescherming en bestuurlijke voorprocedure, Kluwer: Deventer 2006, hoofdstuk 4, R. Kooper, Wie is bang voor de aanvulling van rechtsgronden?, NTB 2000, afl. 6, p. I67-177.

8o. Het aan de orde stellen ter zitting zonder aanknopingspunten in de stukken en vervolgens ambtshalve aanvullen is niet toegestaan, zie ABRvS 3I januari 2007, LJN: AZ7437.

8I. Vgl. ABRvS 2I februari 2007, 20060424I/I, LJN: AZ9015, waarin de Afdeling een uitspraak van de rechtbank vernietigt, omdat de rechtbank bij wijze van ambtshalve aanvulling de Vogelrichtlijn bij de beoordeling had betrokken, maar partijen niet in de gelegenheid had gesteld zich daarover uit te laten. 


\subsubsection{Ambtshalve toepassen van bepalingen van openbare orde}

Deze bepalingen zijn van dwingend recht en worden toegepast buiten de wil van partijen, dit vanuit de gedachte dat er een noodzaak bestaat bepaalde essentiële rechtsnormen te handhaven ondanks de procesintenties van partijen. Hierbij is een verslechtering in rechtspositie van de appèllant wel toelaatbaar. De feiten die nodig zijn voor de ambtshalve toepassing van bepalingen van openbare orde worden verzameld door de rechter zelf. Immers, als deze bepalingen los van de wil van partijen en zelfs tegen hun wil in het geding moeten worden toegepast kan deze toepassing niet afhankelijk worden gesteld van door partijen verstrekte feitelijke gegevens. ${ }^{82}$

Slechts enkele bepalingen zijn tot nu toe in het bestuursprocesrecht als zodanig erkend. ${ }^{8} 3$ Over het algemeen wordt - met een beroep op de memorie van toelichting bij het wetsvoorstel tweede tranche $\mathrm{Awb}^{84}$ - aangenomen dat bepalingen met betrekking tot de bevoegdheid van het bestuursorgaan en de competentie van de rechter van openbare orde zijn. Verder zijn de bepalingen die de ontvankelijkheid van bezwaarschriften en beroepschriften regelen van openbare orde, evenals de regels die de verbindendheid van regelgeving bepalen. ${ }^{85}$ Regels die de goede procesorde bij de rechter bewaken zijn eveneens van dwingend recht. Dit is anders wat betreft de regels van een goede procesorde in het kader van een procedure bij het bestuur. Dat bij voorbeeld een bezwaarmaker in strijd met de regels over het horen door het bestuursorgaan niet is gehoord op zijn bezwaren, acht de Nederlandse bestuursrechter geen zaak die hij ambtshalve moet beoordelen. ${ }^{86}$

Het verschil ten opzichte van de procedure bij de rechter wordt daaruit verklaard, dat de kwaliteit en de legitimiteit van de rechtspraak afhangen van de naleving van de grondregels voor een behoorlijk proces, zodat de rechter zelf en de appèlrechter als toezichthouder op de eerste aanleg ambtshalve moeten nagaan of dit is gebeurd. Voor de bestuurlijke besluitvorming zouden andere reguliere vormen van toezicht bestaan, zodat de nadelen van ambtshalve vernietiging op formele gebreken die een inhoudelijke afdoening verhinderen zwaarder wegen dan het naleven van de regels van een goede procesorde. ${ }^{87}$ Welke vormen van toezicht dat zijn (mogelijk is gedoeld op bestuurlijk toezicht), is me niet geheel duidelijk geworden. Ik vind deze jurisprudentie dan ook niet echt bevredigend, met name wat betreft de uitkomsten over het horen in bezwaar. Dit horen is mijns inziens een fundamentele regel die in de Awb is opgenomen als uitdrukking van de rechten van de verdediging. Daar waar in het stelsel van de Awb het horen in de fase van voorbereiding van een besluit

82. M. Schreuder-Vlasblom, Rechtsbescherming en bestuurlijke voorprocedure, Monografieën Algemene wet bestuursrecht, $\mathrm{A}_{3}$, Kluwer: Deventer 2006, p. I70.

83. Zie voor een overzicht D. Brugman, Ambtshalve toetsing afgebakend, NTB 2005, afl. 8, nr. 34, p. $265-277$.

84. Zie E.J. Daalder e.a., De parlementaire geschiedenis van de Algemene wet bestuursrecht, Tweede tranche, Alphen aan den Rijn: Samsom H.D. Tjeenk Willink I994, p. 464.

85. Vgl. CBb 29 november 2006, LJN: AZ5800. Dit is door de Afdeling bestuursrechtspraak pas recent uitdrukkelijk zo gedaan, zie ABRvS 6 september 2006, LJN: AY7588, AB 2006, 358, m.nt. J.J.J. Sillen.

86. ABRvS 29 juli I996, JB I996/I90, CRvB 7 april I999, JB I999/I23, CRvB 7 februari 200I, AB 200I, 178 , m.nt. HBr.

87. M. Schreuder-Vlasblom, Rechtsbescherming en bestuurlijke voorprocedure, Monografieën Algemene wet bestuursrecht, A3, Kluwer: Deventer 2006,p. I68-I70. 
primair ten doel heeft te komen tot een juiste en volledige feitenvaststelling (zie de artikelen 4:7 tot en met 4:12 Awb) heeft het horen in bezwaar mede ten doel de bezwaarmaker de gelegenheid te geven zich te verweren tegen de beslissing van het bestuursorgaan. Met betrekking tot de voorbereiding van een boete wordt overigens wel aangenomen dat in de primaire fase al het recht op verweer moet bestaan, en is dit tot nu toe geregeld in de bijzondere wetten waarin de bevoegdheid tot het opleggen van een bestuurlijke boete is geregeld. In het wetsvoorstel voor de Vierde tranche van de Awb is voorgesteld om een algemene bepaling inzake het horen voorafgaand aan de bestuurlijke boete in de Awb op te nemen. ${ }^{88}$

Regels betreffende de motivering van besluiten zijn evenmin van openbare orde, evenals regels die uitsluitend kwetsbare belangen van partijen beschermen. De vraag of en zo ja welke bepalingen waarin fundamentele rechten zijn neergelegd, zoals bepalingen van het EVRM, van openbare orde zijn, is tot nu toe niet in algemene zin beantwoord. Dat een aantal fundamentele rechten als zodanig zou worden beschouwd is niet uitgesloten, gedacht vanuit de plicht van de rechter om te toetsen aan hogere (verdrags)normen, mits appellant feiten aanvoert die het vermoeden rechtvaardigen dat er een schending aan de hand is. Met betrekking tot artikel 5 EVRM (recht op persoonlijke vrijheid en veiligheid) heeft de Afdeling bestuursrechtspraak (als hoogste vreemdelingenrechter) ambtshalve toepassing gegeven aan dit fundamentele recht, ${ }^{89}$ maar niet aan artikel 3 EVRM (vrijwaring van foltering). ${ }^{\circ}{ }^{\circ}$ De Hoge Raad (als belastingrechter) deed dit wel met artikel 6, eerste lid, EVRM (redelijke termijn). ${ }^{91}$ Het Straatsburgse Hof verplicht echter niet tot ambtshalve toepassing (noch overigens tot ambtshalve aanvulling). Bij de beoordeling of de nationale rechtsmiddelen zijn uitgeput, stelt het Hof de klager zelf verantwoordelijk voor het opwerpen van de schending van het EVRM tijdens de nationale procedure. Deze kan daaraan niet ontkomen door te stellen dat de schending ambtshalve door de nationale rechter onderzocht had moeten worden. ${ }^{92}$

\subsubsection{Het probleem van de ambtshalve toepassing van het EG-recht}

In Nederland is de discussie over het gebruik van de bevoegdheid tot ambtshalve aanvulling en toetsing aan bepalingen van openbare orde de laatste jaren vooral gevoerd in relatie tot de toepassing van gemeenschapsrecht. Daarbij rees de vraag in hoeverre het gemeenschapsrecht, en in het bijzonder de jurisprudentie van het Hof van Justitie inzake effectieve rechtsbescherming, vereist dat een ruime interpretatie wordt gegeven aan artikel 8:69, tweede lid, Awb (aanvullen van rechtsgronden), dan

88. Dat wil zeggen: als die boete hoger is dan $€ 340$. Zie het (gewijzigde) voorstel van wet, Aanvulling van de Algemene wet bestuursrecht (Vierde tranche Algemene wet bestuursrecht) Kamerstukken I, 2006-2007, 29702 A, artikel 5.4.2.6. Inwerkingtreding van deze wet is voorzien voor I januari 2008.

89. ABRvS II februari 2005, JV 2005, I72, m.nt. Widdershoven.

90. ABRvS 28 mei 2003, 200302I9I/I, LJN: AR5II9.

9I. HR 22 april 2005, AB 2006, II, m.nt. Jansen.

92. Zie EHRM 15 november I996, Ahmet Sadik v. Griekenland, $n^{\circ}$ 46/1995/552/638, ov. 33. Zie over de ontvankelijkheidsjurisprudentie van het EHRM T. Barkhuysen, Het EVRM als integraal onderdeel van het Nederlandse materiële bestuursrecht, in: De betekenis van het EVRM voor het materiële bestuursrecht, VAR-reeks I32, p. 3I-34. 
wel vereist dat ambtshalve, ook buiten hetgeen partijen hebben aangevoerd, toepassing wordt gegeven aan het gemeenschapsrecht. De jurisprudentie van het Hof houdt - zoals bekend - in dat in geval een nationale rechter naar nationaal recht een bevoegdheid heeft tot ambtshalve toepassing of aanvulling, hij verplicht is deze te gebruiken ter toepassing van EG-recht; in geval het hem naar nationaal recht verboden is ambtshalve toe te passen of aan te vullen, moet hij nagaan wat de grondslag is van dit verbod en of die rechtvaardigt dat toepassing van het gemeenschapsrecht achterwege blijft (procedurele rule of reason). ${ }^{93}$

Deze discussie raakte verweven met de discussie over rechtstreekse werking van richtlijnen, omdat werd betoogd dat indien geen beroep werd gedaan op rechtstreeks werkende richtlijnbepalingen de rechter deze - ambtshalve - zou moeten toepassen, dit met een beroep op het arrest Kraaijeveld. ${ }^{94}$ De Afdeling bestuursrechtspraak oogstte grote kritiek op tegenstrijdige uitspraken met betrekking tot de ambtshalve toepassing van milieurichtlijnen, ${ }^{95}$ en op het oog tegenstrijdige rechtspraak met betrekking tot de ambtshalve toepassing van artikel I8 EG (Europees burgerschap). ${ }^{96}$ Kritiek op laatstgenoemde uitspraken was niet terecht, aangezien de Afdeling daarin toepassing gaf aan de rechtspraak van het Hof. Immers ging het in de ene zaak om een geval waarin geen feiten of rechtsgronden was aangevoerd op grond waarvan een relatie kon worden gelegd met artikel I8, terwijl een dergelijke bepaling naar Nederlands recht niet van openbare orde is. ${ }^{97}$ In de andere zaak had appellant feiten aangevoerd op grond waarvan de Afdeling de rechtsgronden kon aanvullen met de EG-bepaling terzake.

In dit verband is in de literatuur discussie ontstaan over de vraag in hoeverre bepalingen van gemeenschapsrecht van openbare orde zouden zijn. Jans heeft in zijn oratie betoogd dat een groot aantal regels die het Hof van Justitie als fundamenteel heeft bestempeld als zijnde van openbare orde door de Nederlandse (bestuurs)rechter ambtshalve zouden moeten worden toegepast. Hij doelt daarbij op regels over het vrije verkeer van personen, goederen en diensten, het beginsel van gelijke behandeling en het reis- en verblijfrecht voor hen die het Europese burgerschap bezitten..$^{8}$

Jans' opvatting is omstreden, omdat de bepalingen die hij noemt niet equivalent zijn met bepalingen die naar Nederlands recht van openbare orde zijn en het Hof ze zelf weliswaar als fundamenteel heeft beschouwd, maar tot nu toe niet heeft geëist

93. HvJEG I4 december I995, C-430/93 en C-431/93, Van Schijndel en Van Veen, Jur. I995, I-4705, BNB I996/276 en HvJEG I4 december 1995, C-3I2/93, Peterbroeck, Jur. I995, I-4599.

94. HvJEG 24 oktober I996, C-72/95, Jur. I996, I-5403, AB I997, I33, m.nt. ChB.

95. Zie bij voorbeeld ABRvS I5 januari 2003, AB 2003, I28 (geen ambtshalve toetsing aan de IPPCrichtlijn) en ABRvS ig februari 2003, AB 2003, I29, m.nt. JV (ambtshalve toetsing aan de IPPCrichtlijn).

96. ABRvS 2 maart 2004, AB 2004, I52, m.nt. BPV en RW (geen ambtshalve toetsing aan artikel I8) en ABRvS 26 juli 2004, JB 2004, 337, m.nt. C.L.G.F.H.A. (ambtshalve aanvulling van rechtsgronden met artikel I8). Zie de kritiek van J.H. Jans, Recht en Vreemdelingerecht, NJB 2004, afl. 22, p. II26.

97. Weliswaar had de rechtbank de kwestie op de zitting aangesneden, maar eiser had slechts beaamd dat de rechter ambtshalve zou moeten toetsen. Niet echte handig van de gemachtigde, aangezien hij door onmiddellijk zelf een beroep te doen op artikel i8 de rechter het instrument van artikel 8:69, tweede lid, Awb in handen had kunnen spelen.

98. J.H. Jans, Doorgeschoten, Enkele opmerkingen over de gevolgen van de Europeanisering van het bestuursrecht voor de grondslagen van de bestuursrechtspraak, Europa Law Publishing: Groningen 2005 , p. I2. 
dat deze ambtshalve - los van de bevoegdheden daartoe naar nationaal recht worden toegepast. ${ }^{99}$ Immers geldt hier ook de procedurele autonomie van de lidstaten die alleen op basis van het gelijkwaardigheids- en effectiviteitsbeginsel wordt doorbroken. Dit is voor het bestuursrecht onlangs bevestigd in het arrest Van der Weerd, ${ }^{\text {IOO }}$ waarin het Hof in antwoord op de vraag of bepalingen van een richtlijn over de bestrijding van mond- en klauwzeer ambtshalve moeten worden toegepast, ook al valt dat buiten de omvang van het geding, zegt dat deze richtlijnbepalingen niet gelijkwaardig zijn aan de regels die naar Nederlands recht van openbare orde zijn. Vervolgens onderzoekt het Hof of het effectiviteitsbeginsel wordt geschonden als de richtlijnbepalingen niet ambtshalve worden toegepast, waarbij het Hof concludeert (na vermelding van de rechtspraak inzake Van Schijndel en Van Veen) dat dit niet het geval is, en dat de beperking bij de ambtshalve toepassing zijn rechtvaardiging vindt in het feit dat het initiatief voor een procedure bij partijen ligt en de rechter alleen bij uitzondering, in het openbaar belang, ambtshalve kan optreden.

Op het voorgaande is wel mogelijk wel een uitzondering. Uit een tweetal arresten (Manfredi en Eco Swiss) zou men kunnen afleiden dat het Hof van Justitie artikel 8I en 82 EG als van openbare orde beschouwt, zodat ook de Nederlandse bestuursrechter deze ambtshalve moet toepassen. ${ }^{\text {IOI }}$ Een nadere beschouwing van deze arresten leert dat in het geval van Eco Swiss de bijzondere situatie van rechterlijke controle van een arbitraal vonnis aan de orde was. Indien artikel 8I EG niet ambtshalve zou kunnen worden toegepast door de controlerende rechter, zou het absoluut onmogelijk zijn om terzake een prejudiciële verwijzing naar het Hof van Justitie te doen, aangezien arbiters niet de bevoegdheid daartoe hebben. Om die reden heeft het Hof artikel 8I beschouwd als bepaling van openbare orde in de zin van artikel ro6 $5 \mathrm{Rv}$ (het nationale recht dus). Deze situatie is vergelijkbaar met de zaak Peterbroeck, waarin het vrijwel onmogelijk of uiterst moeilijk was om vragen van EG-recht voor te leggen aan een rechter. Daar waar in Peterbroeck de zaak werd benaderd via het effectiviteitsbeginsel, gebeurde dat in Eco Swiss met hulp van het gelijkwaardigheidsbeginsel.

In de zaak Manfredi heeft het Hof geoordeeld - in het kader van de beoordeling van de ontvankelijkheid van de prejudiciële verwijzing - dat artikel 8I en 82 EG van openbare orde zijn en door de nationale rechter ambtshalve moeten worden toegepast. Gezien de casus die voorlag, zou het vraagstuk van de toepassing naar Nederlands bestuursrecht - zoals door Widdershoven in zijn noot bij dit arrest is uiteengezet - vallen onder de categorie aanvullen van rechtsgronden in de zin van artikel 8:69, tweede lid, Awb. Immers kwam de Italiaanse rechter op grond van de aangevoerde feiten en de toepasselijke Italiaanse bepalingen tot de conclusie dat de prijsafspraken die in het geding waren niet alleen in strijd waren met het Italiaanse mededingingsrecht, maar ook met artikel 8I EG vanwege betrokkenheid van buitenlandse verzekeringsmaatschappijen. De bevoegdheid van de rechter daartoe werd

99. Voor het Europees burgerschap bij voorbeeld HvJEG 2 oktober 2003, C-I48/02, Avello, Jur. 2003, I-II6I3.

Ioo. HvJEG 7 juni 2007, C222/05 t/m C-225/05, n.n.g., AB 2007, 228, m.nt. R.J.G.M. Widdershoven.

Ior. HvJEG I juni I999, C-I26/97, Eco Swiss, Jur. I999, I-3055; HvJEG I3 juli 2006, C-295/04 t/m C-298/04, Manfredi, Jur. 2006, I-66rg, AB 2006, 404, m.nt. R.J.G.M. Widdershoven. 
bestreden door één van de gedaagde partijen, omdat hij dusdoende zou zijn getreden buiten de omvang van het geding, dat zich beperkte tot de vaststelling door de Italiaanse mededingingsautoriteit dat de Italiaanse mededingingswet was geschonden. Omdat hij het EG-recht niet bij de zaak mocht betrekken, zo stelde deze partij, was hij ook niet bevoegd een verwijzing ter zake te doen en werd het Hof verzocht de verwijzing niet ontvankelijk te verklaren.

Toch is hiermee nog niet de vraag definitief beantwoord of als de situatie van aanvullen niet aan de orde is, de artikelen 8I en 82 EG toch door de rechter ambtshalve moeten worden toegepast. Uit een enkele losstaande overweging in het kader van de beoordeling van de ontvankelijkheid van een prejudiciële vraag kan ook moeilijk worden geconcludeerd dat beide bepalingen steeds ambtshalve zouden moeten worden toegepast. Bovendien zou dit de Nederlandse (bestuurs)rechter voor grote problemen stellen, onder meer met betrekking tot de verzameling van de feiten omtrent verboden kartelafspraken en mogelijk misbruik van een machtspositie. Vooralsnog houd ik het erop dat het Hof heeft willen voorkomen dat partijen de ontvankelijkheid van prejudiciële vragen betwisten door zich erop te beroepen dat de nationale rechter is getreden buiten de omvang van het hoofdgeding.

Anders dan wel wordt gesteld op grond van het voorgaande ${ }^{\mathrm{IO} 2}$ is het niet uitgesloten dat het Hof het wel degelijk mogelijk acht dat (materieelrechtelijke) bepalingen van gemeenschapsrecht dwingend moeten worden toegepast. Daarbij valt te wijzen op de consumentenrichtlijn, waarvan het Hof in een tweetal arresten heeft gesteld dat deze ambtshalve moet worden toegepast omdat de noodzaak van de doeltreffende bescherming van de consument dit ingeeft. ${ }^{103}$ Ook in het arrest Van der Weerd geeft het Hof een aanwijzing in die richting, daar waar het overweegt dat de richtlijnbepalingen waarvan de vraag was of zij ambtshalve moesten worden toegepast behoren tot het beleid op het gebied van de volksgezondheid. ${ }^{\text {IO4 }}$ Daarmee lijkt het Hof een voorzetje te geven, dat dergelijke bepalingen mogelijk toch wel van zodanig belang kunnen zijn dat zij wel ambtshalve moeten worden toegepast. Mogelijk heeft het Hof een opening willen houden voor gevallen waarin bescherming van de individuele, zwakkere partij tegen aantasting van zwaarwegende belangen aan de orde is, zoals het geval is bij het belang van het individu bij bescherming tegen dwangcontracten of bij bescherming van zijn gezondheid. Het is ook mogelijk dat het Hof hiermee de bescherming van belangen die behoren tot het algemeen (gemeenschapsrechtelijke) belang beoogt. Op deze plaats kan dit alles niet worden uitgewerkt, zodat het bij speculatie moet blijven.

102. Vgl. Brugman in haar artikel in NTB en Widdershoven in zijn noot bij Van der Weerd, AB 2007, 229.

I03. HvJEG 27 juni 2000, Océano, C-240/98-C-244/98, Jur. I-494I en HvJEG 26 oktober 2006, Mostaza Claro, C-I68/05, Jur. I-I042I.

I04. HvJEG 7 juni 2007, C-222/05 tot en met C-225/05, n.n.g., AB 2007, 228, m.nt. R.J.G.M. Widdershoven, punt 32. 


\subsubsection{Het bijzondere geval van de belastingrechtspraak}

Sinds I januari 2005 kennen we in de belastingrechtspraak twee feitelijke instanties en cassatieberoep op de Hoge Raad. Voor de twee feitelijke instanties is het Awbprocesrecht van toepassing, waaronder artikel 8:69 Awb. Zij volgen in beginsel de hiervoor uiteengezette doctrine met betrekking tot ambtshalve toepassing en ambtshalve aanvulling. In cassatie is artikel 8:69 Awb niet van toepassing (gelet op artikel 29 Algemene wet inzake rijksbelastingen (Awr) en geldt de afwijkende bepaling van artikel 29 e, tweede lid, Awr, inhoudend dat de Hoge Raad de aangevallen uitspraak vernietigt hetzij op de in het beroepschrift aangevoerde gronden, hetzij op andere gronden. Dit betekent dat de Hoge Raad als belastingrechter een ruime bevoegdheid heeft om ambtshalve te toetsen en zich daarbij niet hoeft te beperken tot bepalingen die van openbare orde zijn. Wel zal het nodig zijn dat er voldoende feitelijke gegevens aanwezig zijn om over te gaan tot ambtshalve toetsing. Immers kan de Hoge Raad niet, ook niet als belastingrechter, de feiten vaststellen, maar moet hij uitgaan van de feiten zoals die in eerdere instanties zijn vastgesteld. ${ }^{105}$ Widdershoven heeft erop gewezen dat dit een vreemde situatie in het leven roept: de gerechtshoven kunnen als belastingrechter geen rechtsgronden bij de beoordeling betrekken die niet worden gesteund door de aangevoerde feitelijke gronden of van openbare orde zijn, terwijl de Hoge Raad, rechtsprekend als hoogste rechter, dat wel kan. ${ }^{\text {I06 }}$ Dat de Hoge Raad deze bevoegdheid heeft, verwondert niet vanuit de gedachte dat cassatie een controlerende functie heeft en dient ter bevordering van de rechtseenheid en de rechtsvorming. Cassatie in belang der wet staat in belastingzaken niet open, zodat op een andere wijze - langs de weg van ambtshalve toepassing - een uniforme en juiste toepassing van het recht moet worden bewaakt.

\section{$5 \cdot 3.8$ Conclusie}

De hiervoor gedane constatering met betrekking tot de bevoegdheid in cassatie van de belastingrechter is mijns inziens van belang voor de bestuursrechtelijke appèlinstanties. Immers, zolang de huidige situatie van meer hoogste bestuursrechters zonder rechtseenheidsvoorziening blijft bestaan, zijn zij ieder voor zich belast met het bewaken van een juiste toepassing van het recht en van de rechtseenheid. De controlerende functie die de Hoge Raad heeft als cassatierechter ligt daarmee (buiten het belastingrecht) in hun handen. Dit betekent ook, dat waar het gaat om de hiervoor uiteengezette ambtshalve toepassing van het recht en de ambtshalve aanvulling van rechtsgronden zij ruimhartig gebruik zullen moeten maken van deze mogelijkheden om deze controletaak goed te kunnen uitvoeren. Daarbij past niet dat vanuit een strikte opvatting ten aanzien van de uitleg van artikel 8:69, tweede lid, Awb, of ten aanzien van het antwoord op de vraag of sprake is van recht van openbare orde wordt afgedaan aan deze controlefunctie. In die zin - zij het op andere

I05. Zie de conclusie van AG Wattel bij HR 7 mei 2004, AB 2004, 347, m.nt. RW, BNB 2004/262, m.nt. Meussen.

Io6. Zie zijn annotatie in $\mathrm{AB} 2004,347$. 
gronden - onderschrijf ik de kritiek van Jans op de praktijk van de ambtshalve toepassing van het gemeenschapsrecht.

\subsection{Afdoening na vernietiging van de lagere uitspraak}

Afhankelijk van de grondslag van de vernietiging van de uitspraak van de rechtbank kan de appèlrechter de zaak wel of niet zelf afdoen. Er bestaan daartoe verschillende uitspraakbevoegdheden (zie artikel 8:72 Awb). Het uitgangspunt is dat de appèlrechter de zaak zoveel mogelijk definitief beslecht. Daarbij past niet dat een zaak wordt teruggewezen naar de rechtbank, al sluiten de procesrechtelijke regels dat niet uit. ${ }^{107}$ Deze regels zijn voor de drie appèlrechters nagenoeg gelijkluidend en bepalen dat de appèlrechter de uitspraak van de rechtsbank bevestigt of vernietigt en in het laatste geval doet wat de rechtbank had behoren te doen. Terugwijzen naar de rechtbank geschiedt indien de uitspraak van de rechtbank dat zij niet bevoegd of het beroep niet ontvankelijk is wordt vernietigd, of in geval de appèlrechter om andere redenen van oordeel is dat de zaak opnieuw door de rechtbank moet worden behandeld. Voor zover ik weet is terugwijzen om de laatste reden in de praktijk uitzonderlijk.

Heeft de rechtbank ten onrechte het beroep gegrond verklaard en de bestreden beslissing vernietigd waar de bestreden beslissing in stand had moeten blijven, dan volstaat een vernietiging van de uitspraak. De bestreden beslissing herleeft en er zijn geen andere voorzieningen nodig.

Indien de rechtbank het beroep ten onrechte ongegrond heeft geacht en de bestreden beslissing is intact gebleven, dan zal de appèlrechter in de regel de zaak niet terugwijzen naar de rechtbank voor een verdere behandeling. Het uitgangspunt is dat de appèlrechter indien hij het hoger beroep gegrond acht zelf het bestreden besluit beoordeelt en aldus doet wat de rechtbank had behoren te doen. In een enkel geval volgt na vernietiging van het bestreden besluit een gedektverklaring van de rechtsgevolgen, hetgeen inhoudt dat het besluit is vernietigd maar de rechtsgevolgen ervan in stand blijven.

In een ander geval vernietigt appèlrechter de uitspraak van de rechtbank en voorziet hij zelf in de zaak door de bestreden beslissing vernietigen en het bestuursorgaan op te dragen een nieuwe beslissing op bezwaar te nemen. Daartegen staat weer beroep in eerste aanleg open met daarna hoger beroep. Indien de appèlrechter de bestreden beslissing vernietigt, kan hij ook doen wat het bestuursorgaan had behoren te doen, namelijk het herroepen van het primaire besluit. In die situatie behoeft het bestuursorgaan in beginsel niets meer te doen, tenzij het gaat om een besluit tot buiten behandeling stellen van een aanvraag bij voorbeeld (artikel 4:5 Awb), want dan moet het de aanvraag alsnog behandelen.

Dat na de uitspraak van de appèlrechter weer opnieuw een volledige ronde van behandeling van het bezwaar, beroep en hoger beroep moet worden gelopen, wordt als onnodig tijdrovend en omslachtig gezien, te meer omdat het geschil zich over het

I07. Zie de artikelen 26 en 28 Wet bestuursrechtspraak bedrijfsorganisatie, 24 en 26 Beroepswet en 42 en 44 Wet op de Raad van State. 
algemeen heeft toegespitst op slechts enkele punten, hetzij van feitelijke, hetzij van juridische aard. Na jaren komt dezelfde zaak weer bij de appèlrechter en men is geen stap verder. Met name in het economisch en ordenend bestuursrecht wordt het bezwaarlijk geacht, dat het daardoor niet komt van een snelle en finale geschillenbeslechting. Voor deze situatie heeft de Commissie Ilsink het voorstel ondersteund om de appèlrechter de bevoegdheid te geven te bepalen dat tegen de nieuwe beslissing op bezwaar direct beroep openstaat bij de appèlrechter, ook wel aangeduid als judiciële lus of als sprongberoep na vernietiging. ${ }^{\text {108 }}$ De Commissie verbetervoorstellen bestuursrecht heeft een vergelijkbaar voorstel gedaan, maar daarbij voorgesteld dat steeds na vernietiging door de appèlrechter slechts beroep bij de appèlrechter openstaat. ${ }^{\text {I09 }}$ Het voorstel is nog niet overgenomen door de regering.

In dit verband kan ook worden gewezen op het voorstel om te komen tot de invoering van een zogenoemde bestuurlijke lus, dat na een langdurige roep om invoering in de literatuur is opgenomen in het voorontwerp Wet aanpassing bestuurprocesrecht. Dit instrument geeft de rechter, en als ik het goed zie ook de appèlrechter, de bevoegdheid om indien hij het beroep gegrond acht het bestuursorgaan in de gelegenheid stellen het gebrek dat leidt tot gegrondverklaring van het beroep te herstellen. Ook dit voorstel heeft ten doel een finale geschilbeslechting te bevorderen. Het voorkomt dat het bestuursorgaan een nieuw besluit neemt dat opnieuw de toets der kritiek niet kan doorstaan en dat tot een nieuw beroep aanleiding geeft. De gedachte is dat de rechter in een tussenuitspraak vermeldt welke gebreken hij ziet in het bestreden besluit en vervolgens het bestuursorgaan de gelegenheid biedt een nieuw, niet gebrekkig besluit te nemen. Dit nieuwe besluit laat de rechter bij zijn einduitspraak vervolgens in stand als tenminste de gebreken genoegzaam zijn hersteld. Deze bevoegdheid is alleen nodig voor gevallen waarin het bestuursorgaan beleidsof beoordelingsvrijheid heeft. Anders kan de rechter immers de zaak zelf afdoen door zelf in de zaak te voorzien en te doen wat het bestuursorgaan had behoren te doen.

Deze wettelijke bevoegdheden worden als gezegd voorgesteld omdat is gebleken dat de bestuursrechter, waaronder ook de appèlrechters, te weinig komen tot finale geschillenbeslechting. ${ }^{\text {IIO }}$ Met name vernietigingen van besluiten van bestuursorganen wegens formele gebreken, zoals een onzorgvuldige voorbereiding of een gebrekkige motivering van het besluit, komen nogal veel voor, en leiden niet tot een

108. Commissie Evaluatie Awb III, Toepassing en effecten van de Algemene wet bestuursrecht 20022006, Derde evaluatie van de Algemene wet bestuursrecht 2006, Boom Juridische uitgevers: Den Haag 2007, p. 45-46; Het door de Commissie Ilsink gesteunde voorstel is gedaan door een onderzoeksgroep die de derde evaluatie van de Awb mede heeft voorbereid. Zie B.J. Schueler e.a., Definitieve geschilbeslechting door de bestuursrechter, Derde evaluatie van de Algemene wet bestuursrecht 2006, Boom Juridische uitgevers: Den Haag 2007, p. I68.

I09. Commissie verbetervoorstellen bestuursrecht, Eindrapport, uitgave Raad voor de rechtspraak, Den Haag 2006, voorstel 4.2.

IIo. Zie het aangehaalde empirische onderzoek van Schueler c.s., waaruit blijkt dat rechters bevoegdheden die zij hebben tot zelf afdoen (artikel 8:72 Awb) of het passeren van vormgebreken (artikel 6:22 Awb) weinig gebruiken (p. 87-Ior en I6o). Uit (een beperkt opgezet) ander onderzoek blijkt overigens dat de Centrale Raad van Beroep het niet slecht doet op het punt van de finaliteit, zie F. Bruinsma/M.L. Vermeulen, Een zelfportret van de Centrale Raad van Beroep, in: R.M. Van Male c.s. (red.), Centrale Raad van Beroep I903-2003, Sdu Uitgevers: De Haag 2003, p. 6I-80 (67). 
definitief einde van het geschil. Immers, na vernietiging door de rechter neemt het bestuursorgaan fris en vrolijk opnieuw inhoudelijk hetzelfde besluit, maar dan nu wel behoorlijk voorbereid of gemotiveerd. Tegen de inhoud - waar het om gaat komt de betrokken burger vervolgens opnieuw op bij de bestuursrechter en de cirkel is compleet.

\section{$6 \quad$ Bewaking van de kwaliteit van de appèlrechtspraak}

\section{I Kwaliteitsmetingen}

Kwaliteitsbewaking en -meting is sinds enige tijd een aandachtspunt in de Nederlandse rechtspraak. Tal van onderzoeken en metingen zijn gedaan om te bezien hoe de staat van de kwaliteit van 'de rechtspraak' is. Als indicatoren worden in de verschillende onderzoeken wel genoemd de lengte van de doorlooptijd, de integriteit en onpartijdigheid van de rechter, de bejegening van partijen in het vooronderzoek en op zitting en de motivering en inhoudelijke kwaliteit van de uitspraak. Verder wordt ook wel als indicator voor de kwaliteit van een uitspraak genoemd de leesbaarheid. Er zijn allerlei metingen verricht ten aanzien van de doorlooptijden en tevredenheidsonderzoeken gedaan onder de 'afnemers' van de producten van de rechtspraak. Dergelijke metingen betreffen echter niet zozeer de juridisch-inhoudelijke kwaliteit van het werk, maar meer de wijze waarop procespartijen de procedure beleven en welke eisen zij daaraan stellen.

In zijn jaarrede voor de VAR, vereniging voor bestuursrecht, heeft Van Ettekoven aandacht besteed aan het onderwerp van de juridisch-inhoudelijke kwaliteit van de

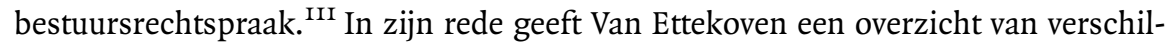
lende onderzoeken, evaluaties en verbetervoorstellen die recent het licht hebben gezien. Mede op grond van deze onderzoeken bepleit hij ter bevordering van de inhoudelijke kwaliteit van de zaaksbehandeling een gerichte zaakselectie met een bewust gedifferentieerde behandeling van de geselecteerde zaken (de zogenoemde poortselectie). Zo kunnen zaken waarvoor een korte, eenvoudige procedure en behandeling voldoende is, worden gescheiden van de ingewikkelder of maatschappelijk meer gewichtige zaken die een diepergaande behandeling nodig hebben.

Dat na de aandacht die was gericht op de kwantitatieve aspecten van de rechtspraak (zoals het wegwerken van zaaksachterstanden, het beperken en verkorten van doorlooptijden, het snel en efficiënt afdoen van zaken) de aandacht meer wordt gericht op de kwalitatieve aspecten is van groot belang. Tot nu toe is wat het bestuursrecht betreft die aandacht vooral gericht geweest op de kwaliteit van de rechtspraak in eerste aanleg. De bewaking van de juridisch-inhoudelijke kwaliteit van de eerste aanleg is in handen gelegd van de appèlinstanties. In het rapport Kwaliteit van de rechtspraak ${ }^{\mathrm{II} 2}$ wordt in de inleiding opgemerkt dat hoger beroep en

III. B.J. van Ettekoven, Agenda voor de bestuursrechtspraak (het einde van de eenheidsworst), Voorzittersrede Jaarvergadering VAR II mei 2007, te raadplegen op: www.verenigingvoorbestuursrecht.nl.

II2. Rapport van 24 augustus 2006, te vinden op http://www.rechtspraak.nl/Gerechten/RvdR/Kwaliteit+van+de+Rechtspraak.htm. 
cassatie (het rapport gaat niet alleen over bestuursrechtspraak) zien op de feitelijk gerealiseerde juridische kwaliteit van het rechtspreken in procedurele en materiële zin. De resultaten van de kwaliteitsmeting die op deze manier gebeurt is echter, aldus het rapport, minder toegankelijk omdat deze zich richt op individuele zaken en niet bestaat uit algemene bevindingen. ${ }^{\mathrm{II} 3}$ Voor de appèlinstanties bestaat uit de aard der zaak een dergelijke wijze van kwaliteitsmeting niet. Een hogere toeziende rechter ontbreekt. Het is daarom inherent aan de positie van deze hoogste instanties, dat zij zelf hun kwaliteit bewaken. Dat kunnen zij doen door intern maatregelen ter bewaking van de kwaliteit te nemen, zoals coördinatie op het gebied van belangrijke algemene rechtsvragen, het voeren van onderling overleg over oplossingsrichtingen, het bewaken van een eenmaal uitgezette jurisprudentielijn en nabespreken van gedane uitspraken, eventueel mede aan de hand van commentaren die zijn verschenen op uitspraken. Aan deze instrumenten kunnen mogelijk enkele worden toegevoegd, die op dit moment voorwerp van discussie zijn naar aanleiding van voorstellen die zijn gedaan door de regering of in de rechtsgeleerde literatuur. Het gaat om de invoering van een zogenoemde 'grand chamber' en om het inrichten van een AG-functie. Hierna worden beide voorstellen besproken.

\subsection{Grand chamber}

Ter bevordering van de rechtseenheid en de rechtsontwikkeling wordt in het voorontwerp Wet aanpassing bestuursprocesrecht voorgesteld dat de bestuursrechtelijke appèlinstanties de mogelijkheid krijgen om een zaak te verwijzen naar een grote kamer van vijf rechters (voorgesteld artikel 8:Ioa Awb). Deze mogelijkheid geldt niet voor de hoven in belastingzaken, aangezien zij niet rechtspreken in laatste instantie en de Hoge Raad nog boven zich hebben. De grote kamer zal dan zaken behandelen die de organisatorische eenheden (secties, kamers, afdelingen) van een appèlinstantie overstijgen en waarvoor het nodig is dat een eenduidige lijn wordt uitgezet. Door te verwijzen naar een grote kamer makt het gerecht ook aan de buitenwereld duidelijk dat het de rechtsvragen die daar spelen belangrijk vindt en dat de uitspraak ter zake als richtinggevend voor andere zaken moet worden beschouwd. Zo wordt inzichtelijk gemaakt welke zaken belangrijk zijn voor de rechtsontwikkeling.

Dit is nieuw voor de bestuursrechtspraak. Gewoonlijk worden zaken - ook in appèl - hetzij door een unus, hetzij door een meervoudige kamer van drie rechters beoordeeld, waarbij wettelijk gezien meervoudigheid het uitgangspunt is. De vraag rijst dan ook in welk type zaken zo'n grote kamer zijn diensten zou kunnen bewijzen. De Poorter en Hirsch Ballin zien voor de Afdeling bestuursrechtspraak een nuttige toepassing bij de uitleg van bijzondere wetgeving die door meer dan één organisatorische eenheid van de Afdeling wordt bestreken. ${ }^{\text {II4 }}$

Met doorverwijzing naar een grote kamer wordt een helder signaal afgegeven dat een principiële uitspraak op handen is over een onderwerp dat of niet eerder aan bod

II3. P. I rapport.

II4. A.w., p. 66I-662. Zo'n eenheid heet bij de Afdeling een 'kamer'. Bij andere rechtsprekende colleges is de kamer de samenstelling van rechters die een zaak behandelen en heet zo'n organisatorische eenheid sectie of afdeling. 
was, of waarover de ingezette jurisprudentielijn wordt gewijzigd. Het enkele feit dat het gaat om de uitleg van een wettelijke bepaling waar meer organisatorische eenheden mee te maken hebben, lijkt me op zichzelf onvoldoende rechtvaardiging. Immers, een eenduidige uitleg kan ook worden bereikt door van de interne coördinatiemechanismen gebruik te maken. De rechtvaardiging voor invoering kan mijns inziens dan ook niet worden gevonden in de noodzaak intern tot eenduidigheid te komen, maar moet worden gevonden in de noodzaak naar buiten toe duidelijk te maken dat het gaat om een rechtsvraag die door het appèlcollege van groot belang wordt gevonden. Dat behoefte bestaat aan de signaalfunctie blijkt onder meer daaruit dat een wijziging in een jurisprudentielijn door de rechtsgeleerde commentatoren niet altijd als zodanig wordt onderkend, zeker niet als in de uitspraak zelf niet duidelijk staat aangekondigd dat het gaat om een koerswijziging. Daarbij komt dat een uitspraak waarin een belangrijke rechtsvraag wordt beantwoord of waarin een koerswijziging plaatsvindt aan gezag wint, wanneer niet een op het oog toevallige samenstelling van de kamer de uitspraak doet. Om deze reden kan worden ingestemd met het initiatief om de mogelijkheid van het instellen van een grote kamer te openen.

\subsection{Conclusie van een AG}

Anders dan in het straf- en civiele recht kent het bestuursrecht (buiten de belastingrechtspraak) in het algemeen geen cassatie (op enkele zeer specifieke gevallen na). In geval van cassatie voorziet het Nederlandse stelsel erin dat het parket bij de Hoge Raad een conclusie neemt bij wijze van advies aan de rechters over de afdoening van de zaak. Meer in het bijzonder wordt de zaak in een breed perspectief geplaatst en vindt een analyse plaats van de aan de orde zijnde rechtsvragen, de achtergronden daarvan, de toepasselijke wetgeving, jurisprudentie en leerstukken. In de belastingrechtspraak is het nemen van een conclusie, anders dan in de civiele en strafrechtspraak, facultatief (artikel 29d Awr). Partijen krijgen een afschrift van de conclusie en zij kunnen binnen twee weken na verzending van het afschrift van de conclusie hun schriftelijk commentaar daarop aan de Hoge Raad doen toekomen.

Buiten de belastingrechtspraak bestaat het instituut van de AG niet. Iedere hoogste bestuursrechter bereidt zaken op zijn eigen wijze voor; een advies van een 'buitenstaander' hoort daar niet bij. Zo kunnen minder ingewikkelde zaken worden voorbereid door een concept-uitspraak te maken waarin de te beoordelen punten als vraag- of aandachtspunten zijn geformuleerd. Tijdens de behandeling moet dan klaarheid komen over deze punten. Meer ingewikkelde zaken met lastige rechtsvragen kunnen meer diepgaand voorbereid door middel van een instructie. Degene die de instructie maakt, bestudeert de zaak, onderzoekt de feiten, analyseert de aan de orde zijnde rechtsvragen, onderzoekt wetgeving en jurisprudentie (zowel van het eigen college als van collega hoogste bestuursrechters), onderzoekt indien nodig het EG-recht, de rechtspraak van het Hof van Justitie dan wel het Europese Hof voor de Rechten van de Mens en doet voorstellen voor de behandeling en beoordeling van de zaak. Ook tussenvormen zijn denkbaar.

In inhoudelijke zin hoeft een uitgebreide instructie niet onder te doen voor een conclusie van een AG, in procedurele zin heeft zij echter een geheel andere functie. 
Het gaat immers om voorstellen voor behandeling van bij de rechtspraak betrokken mensen. Veelal zitten zij zelf ook op de zaak, en daarmee is het een voorbereiding, die deelt in het geheim van de raadkamer. De instructie kan verder ook de stappen vermelden die nog gezet moeten worden in het vooronderzoek, zoals het opvragen van stukken of het betrekken van (derde) partijen bij een zaak.

In de discussienota Keuzen voor de bestuursrechtspraak van 200I wordt vermeld dat de conclusie van de AG's naar algemene opvatting een belangrijke bijdrage leveren aan de kwaliteit en consistentie van de rechtspraak van de Hoge Raad. ${ }^{\text {II5 }}$ Daarom gaan wel stemmen op om in de gehele bestuursrechtspraak de conclusie in te voeren. Daarmee beoogt men meer dan nu te verzekeren dat de rechtseenheid goed wordt bewaakt, en ook dat de hoogste rechters ondersteuning krijgen bij het uitvoeren van hun rechtsprekende en rechtsvormende taken.

De VAR-Commissie Rechtsbescherming, die in 2004 rapport uitbracht, beveelt de invoering van de conclusie aan, indien zou worden overgegaan tot de instelling van een gemeenschappelijke rechtseenheidskamer (zie hiervoor paragraaf 3 ). ${ }^{\text {II }}$ De Commissie plaatst aldus de conclusie in het bredere perspectief van de rechtsvorming op het algemeen deel van het bestuursrecht, over de grenzen van het concrete geval heen. Daarin zit zeker meerwaarde van het advies van een instituut als de AG. Diezelfde meerwaarde kan worden gevonden op de deelgebieden van het bestuursrecht. Immers, ook daar doen zich ingewikkelde rechtsvragen voor, waarbij ook gedacht moet worden aan vragen met betrekking tot de verhouding tussen nationaal recht en internationaal recht, in het bijzonder het gemeenschapsrecht. Daarbij merk ik op dat die meerwaarde niet alleen kan worden gevonden in appèlzaken. Ook, en misschien wel juist, in zaken waarin de hoogste bestuursrechter in eerste en enige aanleg bevoegd zijn, kunnen zich rechtsvragen voordoen die een bredere benadering nodig hebben dan uitsluitend het bezien van het concrete geval. ${ }^{\text {II7 }}$

Aan de andere kant kan zo'n conclusie niet in alle zaken die bij de hoogste bestuursrechter terechtkomen iets bijdragen. Het is evident dat in zaken die een hoog feitelijk karakter hebben, een advies over rechtsvragen niet zo zinvol is, evenals in eenvoudige zaken met vaste rechtspraak die de hoogste bestuursrechters ook op hun bord krijgen. Dit is ook het geval als het gaat om zaken die in eerste en enige aanleg worden afgedaan, omdat ook daarbij typen zaken zijn die zowel qua feiten als qua rechtsvraag geen wezenlijke problemen oproepen. Over het algemeen gaat het daarbij ook om grote zaaksaantallen, welke zaken in de regel enkelvoudig worden afgedaan. Bij het invoeren van de conclusie zal dan ook niet kunnen worden gekozen voor het verplichte stelsel zoals dat geldt in cassatie bij straf- en civiele zaken, anders zou men het paard achter de wagen spannen. Zelfs wanneer enkelvoudige zaken worden uitgezonderd, kunnen zaken overblijven waarbij de feitelijke vragen overheersen.

II5. P. 55 .

II6. VAR-Commissie Rechtsbescherming, De toekomst van de rechtsbescherming tegen de overheid, Van toetsing naar geschillenbeslechting, Den Haag 2004, p. I5I.

II7. Zie voor een voorbeeld CBb I6 maart 2006, (Stichting ROM-projecten), LJN: AV7337, AB 2007, 22, m.nt. WdO. 
Met betrekking tot het gemeenschapsrecht zie ik een bijzondere meerwaarde. Immers zou in een conclusie niet alleen aandacht kunnen worden besteed aan de regelgeving en aan de rechtspraak van het Hof, maar ook aan de rechtspraak over dezelfde of vergelijkbare vragen in de ons omringende landen. Dit kan belangrijke informatie opleveren over de wijze waarop het gemeenschapsrecht daar wordt opgevat, en ook over de vraag of eventueel een prejudiciële vraag zou moeten worden gesteld. Immers, als de opvattingen binnen de EG uiteenlopen, staat vast dat het niet gaat om een acte clair en ligt de zaak gereed voor prejudiciële verwijzing. In de conclusie zou een voorstel kunnen worden gedaan voor de formulering van de vraag, op welke voorstel partijen vervolgens kunnen reageren. Een van de kritiekpunten op de Nederlandse prejudiciële praktijk binnen de bestuursrechtspraak is immers, dat partijen niet of te weinig worden betrokken bij het voorbereiden van de verwijzing. De conclusie met vraag zou ook kunnen worden voorgelegd aan de zustercolleges, zodat op die manier eveneens een vorm van coördinatie plaatsvindt. Ook op de coördinatie met betrekking tot prejudiciële verwijzingen is - zoals uiteengezet in paragraaf 4 - terechte kritiek geuit door Barkhuijsen. ${ }^{\text {II } 8}$

Wat betreft de inrichting van een 'AG-voorziening' lijkt het mij uit een oogpunt van onafhankelijkheid en objectiviteit noodzakelijk dat de AG organisatorisch los staat van het gerecht waarvoor hij conclusies maakt. Daarmee bedoel ik, dat het me niet juist lijkt om een raadsheer of staatsraad ad hoc of voor een beperkte periode te belasten met een AG-taak. Het lijkt een voor de hand liggende keuze om bij wijze van pilot één of meer van de rechtsprekenden van een gerecht te belasten met de taak adviezen uit te brengen. Zo kan worden bekeken in wat voor zaken het uitbrengen van een advies nuttig en nodig is, en kan men tevens bezien of dit een zodanige belasting met zich brengt dat een apart opgetuigde AG-afdeling met ondersteuning binnen het gerecht zinvol is. Ondanks deze praktische argumenten heb ik aarzelingen. Vanwege de hiervoor aangeduide doelen van het invoeren van de conclusie - het bevorderen van rechtsvorming, het bewaken van de rechtseenheid, het bezien van rechtsvragen in een breed nationaal- en internationaalrechtelijk perspectief - is het mijns inziens noodzakelijk dat degene die de conclusie uitbrengt met enige afstand zaken - ook de concrete gevallen - beziet, en niet wordt beïnvloed door de cultuur en de rechtsopvattingen binnen het betrokken rechtscollege. De conclusie moet kunnen worden uitgebracht vanuit een frisse blik op de zaak, vanuit ook een kritische houding ten aanzien van het bestaande. Dat vaste rechtspraak bestaat op een bepaald leerstuk wil niet zeggen dat deze ook moet worden volgehouden. De maatschappelijke of juridische omstandigheden kunnen zijn veranderd; de concrete zaak kan het inzetten van een uitzonderingslijn rechtvaardigen. Voorstellen daartoe moeten kunnen worden gedaan zonder dat men vanuit de eigen achtergrond als staatsraad of raadsheer wordt gehinderd door gevoelens van trouw aan de eigen rechtspraak (die men vaak zelf mee heeft helpen tot stand brengen) of rechtscultuur. Daarmee wil ik niet zeggen dat zij die vanuit de eigen organisatie een AG-functie zouden gaan vervullen niet integer zijn. Ik zeg slechts dat zelfs de schijn van vooringenomenheid of de mogelijkheid daartoe moet worden vermeden.

II8. Zie hierover paragraaf 4 . 
De taak moet mijns inziens worden vervuld door personen die organisatorisch los staan van het rechtscollege dat het betreft. Men kan zich daarbij verschillende opties voorstellen. Een daarvan is dat ieder van de huidige drie bestuursrechtelijke beroepsinstanties een eigen 'afdeling AG' krijgt, waarin iemand wordt benoemd van buiten het betrokken rechtscollege. Dat zou de meest ambitieuze optie zijn, en waarschijnlijk ook de duurste. Omdat moet worden afgewacht hoe vaak en in wat voor soort gevallen een conclusie zinvol is, heeft deze optie vooralsnog niet mijn voorkeur. Een tweede optie zou kunnen zijn het ad hoc inschakelen van een rechtsgeleerde uit wetenschap of praktijk (niet zijnde de eigen rechtsprekende praktijk) om in bepaalde zwaarwegende zaken een advies uit te brengen. Deze optie vind ik niet zo aantrekkelijk, omdat daarmee de statuur van het advies wordt teruggebracht naar het incidentele geval, en het vragen van een advies een hoge uitzondering zal worden, louter omdat het veel voeten in de aarde heeft. ${ }^{\text {II9 }}$ Een derde mogelijkheid is het instellen van een afzonderlijke organisatie - niet per se behorend tot het openbaar ministerie - door de drie appèlinstanties gezamenlijk. Dit heeft - naast schaalvoordelen - ook het voordeel dat coördinatie van (antwoorden op) bestuursrechtelijke en gemeenschapsrechtelijke vragen wordt bevorderd, nog los van het al dan niet bestaan van een rechtseenheidskamer. Ik wijs daarbij nog op hetgeen ik hiervoor heb opgemerkt over het stellen van prejudiciële vragen. Eventueel kunnen raadsheren en staatsraden worden gedetacheerd bij de AG-organisatie en over en weer over elkaars zaken adviseren. Zo gaan ervaring en expertise hand in hand met de gewenste objectiviteit en afstandelijkheid. Een vierde optie - die enigszins vergelijkbaar is met de derde - is geformuleerd door de Commissie verbetervoorstellen bestuursrecht. Deze houdt in dat het (bestaande) openbaar ministerie op eigen verzoek of ambtshalve kan worden gehoord, waarbij de conclusies worden genomen door een voor alle appèlcolleges gezamenlijk ingericht onderdeel van het openbaar ministerie. ${ }^{\mathrm{I} 20}$

Het welslagen van de invoering van een AG-functie hangt echter vooral af van de wijze waarop de appèlcolleges hun werkzaamheden organiseren. Immers, om zinvol gebruik te kunnen maken van de inbreng van een adviseur als de AG zal tijdig moeten worden gesignaleerd dat een rechtsvraag voorligt, waarbij een advies van nut kan zijn. Dit betekent ook dat voldoende tijd moet kunnen worden genomen om een conclusie voor te bereiden en om partijen te laten reageren op deze conclusie. Deze vereisten gaan moeilijk samen met vormen van zittingsgericht werken, waarbij een dossier pas wordt bestudeerd als de zaak al op zitting is gepland. Zaken zullen dus tijdig geselecteerd moeten worden, en hier kan het door Ettekoven voor de eerste aanleg voorgesteld instrument van de poortselectie goede diensten bewijzen.

\section{$7 \quad$ Slotbeschouwing}

De ontwikkelingen die begin jaren negentig van de vorige eeuw in de Nederlandse bestuursrechtspraak in gang zijn gezet, hebben hun einde nog niet bereikt. Als

II9. De geheimhoudingskwestie lijkt me overigens geen probleem, dat laat zich per geval goed regelen.

I20. Commissie verbetervoorstellen bestuursrecht, Eindrapport, aanbeveling 8.I. 
gevolg van de omstandigheid dat van de oorspronkelijke plannen tot herziening van de rechterlijke organisatie slechts een deel is uitgevoerd zijn vraagstukken die in de herzieningsplannen waren opgelost weer opnieuw en nu moeilijker vraagstukken geworden. In het vraagstuk van de rechtseenheid is nog geen oplossing gevonden, terwijl voor de vragen rondom de functie van het hoger beroep en in relatie daarmee de afbakening van de omvang van het geding door de verschillende appèlcolleges geen eenduidige antwoorden zijn gegeven. Dit heeft tot gevolg dat divergenties - zij het soms kleine - ontstaan bij de uitleg en toepassing van de Algemene wet bestuursrecht en op het stuk van de toepassing van het gemeenschapsrecht. Ook in procedurele zin lopen de wijzen van behandeling van zaken soms uiteen.

De hoogste bestuursrechtspraak in Nederland bevindt zich in een fase van transitie. In bijna twintig jaar is veel veranderd en tot stand gebracht. Voor die tijd was hoger beroep in het bestuursrecht geen regel, zodat de appèlrechtspraak nieuw moest worden opgebouwd. De opbouwfase lijkt nu voorbij en er moet worden vooruitgekeken naar de gewenste (voorlopige) eindtoestand. Dat die eindtoestand zal behelzen dat meer dan één hoogste bestuursrechter zal blijven bestaan, is niet zeker. Hoe ook de organisatie van de hoogste bestuursrechtspraak er ook uit zal komen te zien, bij het doordenken van de gewenste eindtoestand zal aandacht moeten worden besteed aan een aantal aspecten.

De goede dingen van de huidige situatie moeten niet zonder meer worden prijsgegeven. De hoogste bestuursrechtspraak is een gespecialiseerde bestuursrechtspraak waarbij rechters met diepgaande kennis van het materiële bestuursrecht en van het algemene bestuurs(proces)recht optreden. Niet in alle bestuursrechtelijke zaken zijn meer dan één instantie nodig. Eventueel kan een tweede rechterlijke instantie worden uitgesloten voor bagatelzaken. Dat het procesrecht bij de verschillende hoogste colleges qua wettelijke bepalingen en qua procesregeling eenvormig is, is een voordeel voor de justitiabelen. ${ }^{\text {II }}$

Voor de nadelen van de huidige situatie moet een oplossing worden gevonden. Als nadelen heb ik genoemd: het ontbreken van een rechtseenheidsvoorziening, het ontbreken van een eenduidige visie op de functies van het hoger beroep en de uit die visie voortvloeiende consequenties voor de afbakening van de omvang van het geding in hoger beroep, het ontbreken van eenduidigheid en coördinatie op het gebied van prejudiciële verwijzingen (zowel wat betreft de aard en inhoud van verwijzingen als wat betreft de procedure) en het ontbreken van een manier om de kwaliteit van de appèlrechtspraak te bewaken. Voor enkele van deze nadelen heb ik gewezen op mogelijke oplossingen.

De komende jaren zullen uitwijzen langs welke lijnen de hoogste bestuursrechtspraak in Nederland zich zal ontwikkelen, zowel wat betreft de organisatie als wat betreft het procesrecht. Dan zal blijken in hoeverre de hiervoor aangestipte vraagstukken waarvoor de hoogste bestuursrechters staan bij de definiëring van hun taak in de maatschappelijke, nationaal-juridische en internationaal-juridische context tot een oplossing zijn gekomen.

I2I. Zie de Procesregeling bestuursrechtelijke colleges 2006, Stcrt. 2005, nr. 250. De wettelijke bepalingen staan nu nog verspreid over de verschillende wetten (Wet bestuursrechtspraak bedrijfsorganisatie, Beroepswet en Wet op de Raad van State. In de Wet aanpassing bestuursprocesrecht wordt voorgesteld alles over te hevelen naar de Algemene wet bestuursrecht. 